\title{
The Doubtful Existence of Resource Curse ${ }^{\dagger}$
}

\author{
Dong Koo Kim*
}

ABSTRACT : The term, "resource curse", is widely used to describe how countries rich in natural resources, such as oil, natural gas, and certain minerals, are unable to utilize that wealth to boost their economies. Contrary to previous research on the topic, this study has demonstrated that natural resources have a strong positive correlation with a country's economy. It likewise confirmed that this result is robust with broad sets of exogenous variables, and that the positive impact of natural resources on the economy remains significant with the inclusion of capital stock per worker. In this sense, it is doubtful that resource curse actually exists in the long-run.

On the other hand, this study tested whether the quality of institutions has any relation with natural resource endowments if the positive effect of natural resource endowments on the gross domestic product (GDP) is adequately controlled for. In contrast to findings of Alexeev and Conrad (2009), if the former Soviet Union (FSU) countries are included, it seems that there might be a negative and statistically significant relationship between large endowments of natural resources and the quality of institutions. However, this negative relationship loses its significance and some positive albeit insignificant relationships are confirmed in a considerable number of cases when the FSU countries are excluded in the sample. That is, the negative relationship results from the inclusion of the FSU countries. This result is believed to happen by a temporary coincidence of events, a natural resource windfall and political and economic instability during the transition of the FSU countries. Therefore, the argument that resource abundance harms the institutional quality is confirmed to be a little groundless.

Keywords : Resource Curse, Economic Growth, Capital Stock, Institutional Quality, Former Soviet Union

\section{JEL 분류: Q32, 013, D24, 043, P28}

Received: January 18, 2013. Revised: April 8, 2013. Accepted: June 17, 2013.

$\dagger$ This paper is a revised version of Kim (2009). The author gratefully acknowledges the helpful comments of Sunyoung Park, Barry W. Ickes, Hak K. Pyo, Chulhee Rhee, and three anonymous referees. The views presented in this article are those of the author and do not necessarily reflect those of the institution with which the author is affiliated. All remaining errors are mine.

* Research Fellow, Samsung Economic Research Institute, Seoul 137-955, Korea(e-mail: eastnine09@gmail.com) 


\section{자원의 저주에 대한 비판적 고찰 \\ 김 동 구*}

요 약 : “자원의 저주”란 천연자원이 풍부한 국가들이 오히려 경제적으로 낙후되어 있다는 학설 이다. 본 논문에서는 기존 연구들과 달리 천연자원 보유 및 생산량이 경제수준과 강한 양(+)의 회귀계수를 보이는 것으로 분석하고 있다. 이러한 결과는 1 인당 자본스톡 등 경제성장과 연관 된 다양한 설명변수들을 포함시켰을 때에도 유지되고 있다. 이러한 점에서 자원의 저주가 실제 로 존재하는 지는 의문이다.

다음으로 천연자원이 경제에 미치는 긍정적인 영향을 통제하고 나서 천연자원 보유 및 생산량 에 따른 한 나라의 제도발전 정도를 회귀분석한 결과, 구소련지역 국가들을 포함시키게 되면 선행연구인 Alexeev and Conrad(2009)와는 달리 천연자원 보유량이 제도발전 정도와 음(-)의 회귀계수를 가질 수도 있는 것으로 나타났다. 그러나 이러한 음(-)의 회귀계수는 구소련지역 국 가들을 분석대상에서 제외하면 모두 통계적 유의성을 상실하였으며, 통계적으로 유의하지는 않 지만 상당수 분석결과에서는 양(+)의 회귀계수도 도출되었다. 즉, 음의 회귀계수는 구소련지역 국가들에 의해 도출된 것이라고 할 수 있다. 이러한 결과는 구소련 지역 국가들의 체제이행기 서방자본의 유입으로 인한 천연자원 보유 및 생산량의 급증과 체제변환에 따른 정치경제적 불 안정이 동시에 발생한 때문이며, 일시적이고 다분히 우연에 의한 결과로 추정된다. 따라서 천연 자원 보유량이 제도 발전 정도에 부정적인 영향을 미친다는 주장도 그 근거가 다소 희박하다고 하겠다.

주제어 : 자원의 저주, 경제성장, 자본스톡, 제도발전, 구소련지역 국가

접수일(2013년 1월 18일), 수정일(2013년 4월 8일), 게재확정일(2013년 6월 17일)

* 삼성경제연구소 수석연구원(e-mail: eastnine09@gmail.com) 


\section{Introduction}

The term, "resource curse", has been widely employed to describe how countries rich in so-called "point-source" resources, such as oil, natural gas, and certain minerals, were unable to utilize these natural resources to boost their economies. It likewise depicts how these countries experienced lower economic growth compared with other countries lacking the said resources. Since the work of Sachs and Warner (1995), a large body of literature1) has attempted to demonstrate empirically and analyze the resource curse. Most of this literature claimed that they confirmed the negative impact of natural resources on growth, positing that abundance of resources leads to the deterioration of institutions, which triggers a slowdown in growth. In the end, Sachs and Warner (2001) concluded that "empirical support for the curse of natural resources is not bulletproof, but it is quite strong."

However, because of the high soar of crude oil and raw material prices, resource possession and acquisition has been being a hot issue in the current world. The current situation is sometimes described as "war for resource acquisition" and almost every country eager to secure resources. In this sense, the notion of "resource curse" can hardly be in agreement with our common sense and a strong doubt is arisen on the earlier studies.

Alexeev and Conrad (2009) questioned the existence of this curse, underscoring serious technical problems with existing empirical work in favor of the existence of the curse. That is, the existing studies assumed the GDP per capita at a specific point of time (usually, in 1965 or 1970) as the initial GDP level and then, compared the growth rates for 25 or 30 years from the "initial" point. However, as Alexeev and Conrad (2009) pointed out, most oil-producing countries started their

1) The literature on resource curse is vast. Some famous works are: Aslaksen (2010), Carneiro (2007), Collier and Goderis (2008), Gylfason (2001), Holdler (2006), Matsen and Torvik (2005), Mehlum et al. (2006), Torvik (2001, 2002, 2009), Treisman (2010), Polterovich et al. (2010). 
commercial extraction prior to 1950 s. Therefore, even if the economic growth rates of resource-abundant countries since 1970s are turned out to be lower than those of countries without resource endowments, it is possible that the resource-rich countries' economies grew faster than others at the early stage of resource development before 1950s and their economies slow down as the deposits of resources mature.

Suppose a country with constant growth rates of population and GDP, so its per capita GDP follows a linear growth path, $G(t)$, which is expressed as a dashed line at $<$ Figure $1>$. The country can be considered to be cursed by resources if the country follows the two growth paths below after the discovery and commercial exploitation of resources (time $=a$ ). The one is the strong version of resource curs $\mathrm{e}^{2)}$. In this version, the country records lower GDP level shortly after the discovery and commercial exploitation of resources following a solid line growth path $\mathrm{H}(\mathrm{t})$ at the strong curse in $<$ Figure $1>$. Another is the weak version of resource curse ${ }^{3)}$. In this case, the economy initially grows fast due to the resources but after a period of time (time $=s$ ), the growth slows down and its GDP level falls below that without the discovery of resources as expressed at the weak curse in $<$ Figure $1>$.

〈Figure 1〉 Types of Resource Curse by Alexeev and Conrad (2009)

Strong Curse

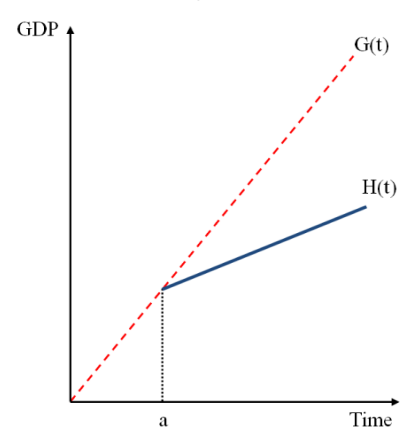

Weak Curse

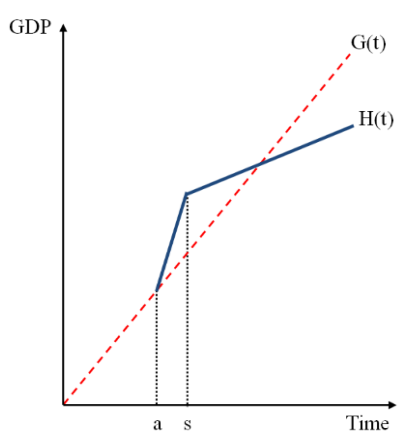

No Curse

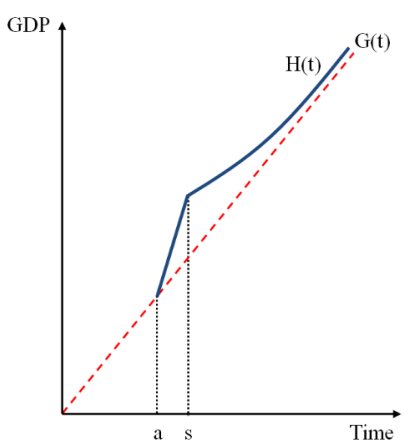

2) This was named by Alexeev and Conrad (2009).

3) This was named by Alexeev and Conrad (2009). 
Of course, it is possible for a resource-rich country not to make the best use of resource endowments because of some negative impacts of resources, for example, on the institutional quality. In this case, the economy enjoys prosperity at the early stage and then will return to its natural growth path as the resources deplete as plotted at no curse in $\langle$ Figure 1 $>$. However, if the GDP level is still higher than it would have been without the discovery of resources, this economy is hardly described to be cursed by resources.

Alexeev and Conrad (2009) demonstrated that high endowments of oil and other minerals have a positive impact on per capita gross domestic product (GDP) level. A country with a higher GDP level should have experienced faster economic growth than a country with a lower GDP level at a certain period in the past. Therefore, the strong version of resource curse cannot be valid according to the Alexeev and Conrad (2009)'s findings. The weak version of resource curse may not be denied although there is a positive relationship between resources and GDP level. However, the previous studies which examined the growth rates for a limited time period hardly be a sufficient enough evidence for the existence of resource curse. That is, the weak version is still invalid until $\mathrm{H}(\mathrm{t})<\mathrm{G}(\mathrm{t})$ is shown. Therefore, Alexeev and Conrad (2009) concluded that natural resource endowments positively affect long-term growth rates of countries. Moreover, they explained that oil and minerals are largely neutral with respect to institutional quality of countries contrary to claims of extant literature on the resource curse.

Although Alexeev and Conrad's research contributed to questioning whether previous research adequately explained the existence of resource curse, their analysis was limited in that it only includes limited number of countries and fails to include several crucial countries in the resource economics. To be specific, they failed to include especially the former Soviet Union (FSU). Without the FSU countries, the analysis can hardly be accurate or robust because its shares of world proved oil reserves and production in 2007 are $10.4 \%$ and $16 \%$, respectively and 
moreover; its shares of world proved natural gas reserves and production in 2007 are $30.2 \%$ and $26.8 \%$, respectively. In the previous research, the number of exogenous variables in the regression model is also substantially small.

In order to overcome the limitation of previous work, this study gathers balanced data with wide range of variables for 151 countries. By including a variety of variables explaining economic growth, it is possible to ensure the robustness of the regression model. Especially, capital stock per worker, which has been considered as the most significant variable in describing economic growth, is also included in the model.

This paper consists of four major sections. First, the impact of natural resources on income level is tested in section II. Capital stock per worker in the regression is introduced. In the succeeding section, the effect of natural resources on institutional quality is analyzed using predicted GDP level. In sections IV and V, the effect of the inclusion of the FSU and the use of different measures in the regression are checked.

\section{Natural Resources and Income Level}

\section{Estimation Approach and Data}

Most of previous analyses in favor for resource curse were skewed by the use of "initial" per capita GDP as a controlling variable, however; the said approach resulted in the comparison of countries having high GDP and good institutions with those that record high GDP purely because of resource wealth, for example; Norway and Kuwait. To eliminate such skewness brought about by using "actual" per capita GDP, recent studies employed exogenous geographical factors to calculate what they believed countries' per capita GDP would be in the absence of oil or mineral wealth. This study follows the cross-sectional approach in order to 
demonstrate the positive effect of natural resources on growth. This method measures long-term growth via GDP per capita levels rather than by calculating growth rates over a given period of time and the method was tapped by Hall and Jones (1999), Easterly and Levin (2003), Rodrik et al. (2004), and Alexeev and Conrad (2009).

In analyzing the impact of natural resources on economic performance, the following regression model is utilized:

$$
Y_{i, T}=\beta_{0}+\sum \beta_{i} X_{i}+\gamma N_{i}+\epsilon_{i}
$$

where $Y_{i, T}$ represents per capita GDP in year $T$ in country $i$ adjusted for purchasing power parity (PPP), $N_{i}$ implies a measure of natural resource endowments, and $X_{i}$ 's are control variables.

In the previous literature, the following measures of oil endowment were employed to estimate regression (1). They were the logarithm of 1993 hydrocarbon deposits per capita from Sala-i-Martin et al. (2004); the logarithm of one plus the country's per capita production of oil in 2000 at world market prices from BP (2005); and the share of oil output in GDP. Although Sala-i-Martin et al. (2004) contributed to works that examine robustness of various explanatory variables in cross-country economic growth regressions, their data is deficient as they failed to include successors of the FSU. As earlier mentioned, it is believed that the FSU is too important in the economics of natural resources that it should not be excluded. A problem in using production data of oil from BP (2005) is that it merely reports production data of 49 major oil-producing nations. Thus, tapping this data may create bias on the effect of oil endowment on GDP toward the major oil-producing countries. Further, since the effect of natural resources on GDP is being analyzed, there is skepticism over the use of a measure of resource expressed as the share of GDP. For example, if a country is burdened by low growth rates and low GDP because of reasons other than oil, it would have a higher share of oil output in 
GDP. This would create a bias toward a negative effect of oil on GDP.

Instead of using the previous measures of natural resources, the present study adopts a different source of natural resource data4). CIA (2008) provides a variety of information on over 200 countries in the world, and the set of data likewise includes proved reserves and daily production of oil and natural gas in each country. To estimate regression (1), two varying measures of oil endowment which are derived from CIA data are employed. One measure of oil endowment is the logarithm of one plus oil reserve per capita in year 2007, while another is the logarithm of one plus the value of the country's per capita oil production at world market price in 2007 US\$. It is believed that using these measures will alleviate the problems of the previous measures of natural resources. Additionally, measures of natural gas endowment derived in the same way are employed. Until now, little attention has been accorded natural gas as a measure of natural resource. However, according to the US Energy Information Administration, energy from natural gas accounted for $24 \%$ of total energy consumed in the US in 2007 , ranking it the second largest energy source. Thus, natural gas endowments are included as a measure of natural resources.

With respect to the dependent variable, this study uses per capita PPP adjusted GDP data from Maddison (2008), which contains a wider set of countries compared with the Penn World Table (PWT) by Heston et al. (2006) which has been usually employed in previous literature. The use of this data especially allows inclusion of successors of the FSU in estimating the effect of natural resource endowment on institutional quality; this is because the data provides per capita PPP GDP levels for successors of the FSU in 1973.

Alexeev and Conrad (2009) utilized two different sets of control variables. One

4) This study does not use resource measures that are expressed as shares of GDP nor the share of resource exports in GDP or in total exports because those measures are likely to bias the result as Alexeev and Conrad (2009) pointed out. Instead, the amount of resource reserve per capita and the value of resource production are used as resource measures. 
set merely includes geographic variables of absolute value of latitude and dummy variables for the European population, Latin America, and East Asia. As the scholars themselves admitted, this set is extremely narrow. The second set includes the measure of institutional quality and degree of ethnolinguistic fractionalization (ELF) as additional regressors. It is believed that their sets of control variables are too parsimonious; thus, this study includes additional exogenous variables. The set of variables in the present study additionally includes dummy variables for sub-Saharan African countries, landlockedness, and the (former) communist economy5).

\section{Results}

First, ordinary least square (OLS) regressions are run solely with exogenous variables. Results of regressions for oil endowments are presented in $\langle$ Table 1$\rangle$. In all regressions, correlation coefficients of oil are positive and statistically significant at $1 \%$ level. In regression [2], by referring to oil reserve and all exogenous variables, elasticity of logarithm of per capita PPP GDP in 2006 with respect to the logarithm of per capita oil reserve is .08 . Elasticity of GDP with respect to oil reserve estimated at the median value of oil reserve (.31) is approximately .025 . The same elasticity evaluated at the mean of oil reserve (.94) is .075 . These results demonstrate that the curse of oil hardly exists.

Instrumental variable (IV) regression is likewise run with an instrumented measure of institutional quality. Good institutions are inclined to enhance economic growth of a country, but it is likewise true that a country with a high GDP level may have high-quality institutions. In this sense, it is important to identify reasonable instruments for measuring institutional quality. Thus, this study uses the rule of law index from the World Bank (2008) and the institutional quality variable by the fraction of population whose mother tongue is English, the fraction of

5) More detailed description and data sources of variables are presented in the Appendix. 
population speaking four primary Western European languages, and absolute value of latitude. These variables are instrument variables employed by Hall and Jones (1999) and Alexeev and Conrad (2009).

〈Table 1〉 Effect of Oil on Per Capita GDP Dependent variable: Logarithm of per capita PPP GDP in 2006

\begin{tabular}{|c|c|c|c|c|c|c|c|c|}
\hline Variable & [1] & {$[2]$} & [3] & [4] & [5] & [6] & [7] & [8] \\
\hline $\begin{array}{l}\text { Oil reserve, } \\
\text { per capita }\end{array}$ & $\begin{array}{c}.116^{* * * *} \\
(.026)\end{array}$ & $\begin{array}{c}.080 * * * \\
(.027)\end{array}$ & & & $\begin{array}{c}.122 * * * \\
(.028)\end{array}$ & $\begin{array}{c}.105 * * * \\
(.024)\end{array}$ & & \\
\hline $\begin{array}{l}\text { Value of oil } \\
\text { output, per } \\
\text { capita }\end{array}$ & & & $\begin{array}{c}.122 * * * \\
(.023)\end{array}$ & $\begin{array}{c}.093 * * * \\
(.024)\end{array}$ & & & $\begin{array}{c}.110^{* * * *} \\
(.024)\end{array}$ & $\begin{array}{c}.098 * * * \\
(.022)\end{array}$ \\
\hline $\begin{array}{l}\text { Absolute } \\
\text { latitude }\end{array}$ & $\begin{array}{c}.013 * * * \\
(.002)\end{array}$ & $\begin{array}{c}.013 * * * \\
(.003)\end{array}$ & $\begin{array}{c}.013 * * * \\
(.002)\end{array}$ & $\begin{array}{c}.013 * * * \\
(.002)\end{array}$ & & & & \\
\hline ELF & & & & & $\begin{array}{c}-.280^{* *} \\
(.114)\end{array}$ & $\begin{array}{l}-.142 \\
(.106)\end{array}$ & $\begin{array}{l}-.276^{* *} \\
(.109)\end{array}$ & $\begin{array}{l}-.141 \\
(.104)\end{array}$ \\
\hline $\begin{array}{l}\text { European } \\
\text { population }\end{array}$ & $\begin{array}{c}.535^{* * *} \\
(.082)\end{array}$ & $\begin{array}{c}.388^{* * * *} \\
(.086)\end{array}$ & $\begin{array}{c}.499 * * * \\
(.076)\end{array}$ & $\begin{array}{c}.368^{* * *} \\
(.080)\end{array}$ & $\begin{array}{l}-.398^{*} \\
(.224)\end{array}$ & $\begin{array}{l}-.134 \\
(.114)\end{array}$ & $\begin{array}{l}-.404 * \\
(.223)\end{array}$ & $\begin{array}{l}-.143 \\
(.114)\end{array}$ \\
\hline Latin America & $\begin{array}{l}.349 * * * \\
(.072)\end{array}$ & $\begin{array}{l}.174 * * \\
(.083)\end{array}$ & $\begin{array}{c}.331 * * * \\
(.072)\end{array}$ & $\begin{array}{l}.171^{* *} \\
(.081)\end{array}$ & $\begin{array}{c}.218^{* * *} \\
(.071)\end{array}$ & $\begin{array}{c}.196^{* * * *} \\
(.073)\end{array}$ & $\begin{array}{c}.207 * * * \\
(.069)\end{array}$ & $\begin{array}{c}.180^{* * *} \\
(.069)\end{array}$ \\
\hline East Asia & $\begin{array}{c}.712 * * * \\
(.128)\end{array}$ & $\begin{array}{c}.515^{* * *} \\
(.120)\end{array}$ & $\begin{array}{c}.624 * * * \\
(.117)\end{array}$ & $\begin{array}{c}.465^{* * *} \\
(.113)\end{array}$ & $\begin{array}{l}.001 \\
(.145)\end{array}$ & $\begin{array}{l}.108 \\
(.076)\end{array}$ & $\begin{array}{l}-.057 \\
(.146)\end{array}$ & $\begin{array}{l}.054 \\
(.074)\end{array}$ \\
\hline Africa & & $\begin{array}{l}-.240 * * \\
(.096)\end{array}$ & & $\begin{array}{l}-.228 * * \\
(.093)\end{array}$ & & $\begin{array}{l}-.130 \\
(.087)\end{array}$ & & $\begin{array}{l}-.139 * \\
(.083)\end{array}$ \\
\hline Landlocked & & $\begin{array}{c}-.149 * * \\
(.070)\end{array}$ & & $\begin{array}{l}-.119^{*} \\
(.071)\end{array}$ & & $\begin{array}{l}-.081 \\
(.060)\end{array}$ & & $\begin{array}{l}-.065 \\
(.060)\end{array}$ \\
\hline $\begin{array}{l}\text { Communist, } \\
\text { former }\end{array}$ & & $\begin{array}{c}-.248 * * * \\
(.066)\end{array}$ & & $\begin{array}{c}-.244 * * * \\
(.064)\end{array}$ & & $\begin{array}{c}.219^{* * * *} \\
(.076)\end{array}$ & & $\begin{array}{c}.197 * * * \\
(.074)\end{array}$ \\
\hline $\begin{array}{l}\text { Rule of law } \\
\text { (Instrumented) }\end{array}$ & & & & & $\begin{array}{c}.641 * * * \\
(.110)\end{array}$ & $\begin{array}{c}.491 * * * \\
(.064)\end{array}$ & $\begin{array}{c}.617 * * * \\
(.111)\end{array}$ & $\begin{array}{c}.469 * * * \\
(.063)\end{array}$ \\
\hline Observations & 151 & 151 & 151 & 151 & 151 & 151 & 151 & 151 \\
\hline $\begin{array}{l}\text { P-value for } \\
\text { Hansen J stat. }\end{array}$ & & & & & .176 & .867 & .218 & .915 \\
\hline Adj. $\mathrm{R}^{2}$ & .606 & .653 & .630 & .670 & .558 & .733 & .585 & .747 \\
\hline
\end{tabular}


However, inclusion of the instrumental variables measuring institutional quality does not harm the result. The results at three out of four regressions demonstrate a stronger positive correlation between GDP and measures of oil endowments than OLS. Thus, the result confirms that there is a natural resource blessing, not a curse in the long-run.

〈Table 2〉 Effect of Natural Gas on Per Capita GDP Dependent variable: Logarithm of per capita PPP GDP in 2006

\begin{tabular}{|c|c|c|c|c|c|c|c|c|}
\hline Variable & [1] & [2] & [3] & [4] & [5] & [6] & [7] & [8] \\
\hline $\begin{array}{l}\text { Natural gas } \\
\text { reserve, per capita }\end{array}$ & $\begin{array}{l}.058^{* * *} \\
(.015)\end{array}$ & $\begin{array}{l}.036^{* *} \\
(.015)\end{array}$ & & & $\begin{array}{l}.071^{* * *} \\
(.014)\end{array}$ & $\begin{array}{l}.055^{* * *} \\
(.012)\end{array}$ & & \\
\hline $\begin{array}{l}\text { Value of natural } \\
\text { gas output, per } \\
\text { capita }\end{array}$ & & & $\begin{array}{c}.044^{* * *} \\
(.011)\end{array}$ & $\begin{array}{l}.027^{* *} \\
(.011)\end{array}$ & & & $\begin{array}{l}.049^{* * * *} \\
(.010)\end{array}$ & $\begin{array}{l}.038^{* * * *} \\
(.009)\end{array}$ \\
\hline Absolute latitude & $\begin{array}{l}.013^{* * *} \\
(.002)\end{array}$ & $\begin{array}{l}.013 * * * \\
(.003)\end{array}$ & $\begin{array}{l}.012 * * * \\
(.002)\end{array}$ & $\begin{array}{l}.012 * * * \\
(.003)\end{array}$ & & & & \\
\hline ELF & $\begin{array}{l}.517 * * * \\
(.083)\end{array}$ & $\begin{array}{c}.366^{* * * *} \\
(.084)\end{array}$ & $\begin{array}{l}.507 * * * \\
(.084)\end{array}$ & $\begin{array}{l}.363^{* * * *} \\
(.085)\end{array}$ & $\begin{array}{l}-.257^{* *} \\
(.108)\end{array}$ & $\begin{array}{l}-.120 \\
(.104)\end{array}$ & $\begin{array}{l}-.257^{* *} \\
(.108)\end{array}$ & $\begin{array}{l}-.120 \\
(.104)\end{array}$ \\
\hline $\begin{array}{l}\text { European } \\
\text { population }\end{array}$ & $\begin{array}{l}.360 * * * \\
(.074)\end{array}$ & $\begin{array}{l}.171^{* *} \\
(.085)\end{array}$ & $\begin{array}{l}.337 * * * \\
(.074)\end{array}$ & $\begin{array}{l}.161^{*} \\
(.085)\end{array}$ & $\begin{array}{l}-.377^{*} \\
(.216)\end{array}$ & $\begin{array}{l}-.150 \\
(.117)\end{array}$ & $\begin{array}{l}-.377^{*} \\
(.216)\end{array}$ & $\begin{array}{l}-.150 \\
(.117)\end{array}$ \\
\hline Latin America & $\begin{array}{c}.659 * * * \\
(.136)\end{array}$ & $\begin{array}{l}.469 * * * \\
(.122)\end{array}$ & $\begin{array}{l}.589 * * * \\
(.140)\end{array}$ & $\begin{array}{l}.431^{* * * *} \\
(.125)\end{array}$ & $\begin{array}{c}.236^{* * * *} \\
(.073)\end{array}$ & $\begin{array}{l}.202 * * * \\
(.077)\end{array}$ & $\begin{array}{c}.236 * * * \\
(.073)\end{array}$ & $\begin{array}{c}.202 * * * \\
(.077)\end{array}$ \\
\hline East Asia & & $\begin{array}{c}-.254^{* * *} \\
(.095)\end{array}$ & & $\begin{array}{l}-.245^{* *} \\
(.096)\end{array}$ & $\begin{array}{l}-.036 \\
(.133)\end{array}$ & $\begin{array}{l}.056 \\
(.071)\end{array}$ & $\begin{array}{l}-.036 \\
(.133)\end{array}$ & $\begin{array}{l}.056 \\
(.071)\end{array}$ \\
\hline Africa & & $\begin{array}{c}-.153^{* *} \\
(.072)\end{array}$ & & $\begin{array}{c}-.157^{* *} \\
(.071)\end{array}$ & & $\begin{array}{l}-.141^{*} \\
(.086)\end{array}$ & & $\begin{array}{l}-.141^{*} \\
(.086)\end{array}$ \\
\hline Landlocked & & $\begin{array}{c}-.265^{* * *} \\
(.065)\end{array}$ & & $\begin{array}{c}-.257^{* * *} \\
(.066)\end{array}$ & & $\begin{array}{l}-.073 \\
(.063)\end{array}$ & & $\begin{array}{l}-.073 \\
(.063)\end{array}$ \\
\hline $\begin{array}{l}\text { Communist, } \\
\text { former }\end{array}$ & .232 & .542 & .008 & .248 & & $\begin{array}{l}.199 * * * \\
(.076)\end{array}$ & & $\begin{array}{c}.199 * * * \\
(.076)\end{array}$ \\
\hline $\begin{array}{l}\text { Rule of law } \\
\text { (Instrumented) }\end{array}$ & & & & & $\begin{array}{c}.622^{* * *} \\
(.107)\end{array}$ & $\begin{array}{c}.489 * * * \\
(.065)\end{array}$ & $\begin{array}{c}.622 * * * \\
(.107)\end{array}$ & $\begin{array}{c}.489 * * * \\
(.065)\end{array}$ \\
\hline Observations & 151 & 151 & 151 & 151 & 151 & 151 & 151 & 151 \\
\hline $\begin{array}{l}\text { P-value for } \\
\text { Hansen J stat. }\end{array}$ & & & & & .139 & .745 & .190 & .771 \\
\hline Adj. $\mathrm{R}^{2}$ & .587 & .640 & .591 & .641 & .581 & .724 & .634 & .738 \\
\hline
\end{tabular}

Notes: Robust standard errors are in parentheses; constant is not shown; *** $\mathrm{p}<.01, * * \mathrm{p}<.05, * \mathrm{p}<.1$. Instruments for rule of law: absolute latitude, English language speakers, European language speakers. 
Results of OLS regressions for natural gas endowments are presented in <Table $2>$. In two out of four regressions, coefficients of the measures of natural gas are strongly positive and statistically significant at $1 \%$ level and coefficients of natural gas endowments in the remaining two regressions are significant at 5\% level. In regression [4], by using natural gas output and all exogenous variables, elasticity of per capita GDP in 2006 with respect to value of natural gas output is .027 . Elasticity of GDP evaluated at the median of natural gas output (3.98) is .107. The same elasticity estimated at the mean (3.13) is .084.

IV regression for the natural gas is likewise run with an instrumented measure of institutional quality. However, inclusion of the instrumental variables measuring institutional quality does not harm the result at all. To the contrary, IV regression results are all significant at $1 \%$ level, demonstrating a stronger positive correlation between GDP and measures of natural gas than OLS.

\section{Effect of Capital Stock per Worker}

The growth of an economy's total output can be decomposed into increases in the amount of factors used - usually the increase in amount of capital and laborand that which cannot be accounted for by observable changes in factor utilization. In addition to the conventional two factors, some research works consider natural resources as the third factor. Inclusion of capital-labor ratio in the regression reveals the impact of natural resource abundance on the economy given the capital stock per worker. Owing to limited data on capital stock and for more precise comparison, this study employed conventional variables (i.e., logarithm of per capita PPP GDP in 2000 from PWT 6.2) and resource measures (i.e., hydrocarbon deposits, value of oil output in 2000, and oil/GDP ratio). Unpublished capital stock per worker (KapW) from the PWT 6.2 is utilized as capital-labor ratio. 
〈Table 3〉 Effect of Capital Stock on Per Capita GDP by PWT I [OLS] Dependent variable: Logarithm of per capita PPP GDP in 2000 by PWT

\begin{tabular}{|c|c|c|c|c|c|c|}
\hline Variable & [1] & [2] & [3] & {$[4]$} & {$[5]$} & {$[6]$} \\
\hline $\begin{array}{l}\text { Hydrocarbon deposits, } \\
\text { per capita }\end{array}$ & $\begin{array}{c}.027 * * * \\
(.008)\end{array}$ & & & $\begin{array}{l}.025 \\
(.017)\end{array}$ & & \\
\hline $\begin{array}{l}\text { Value of oil output in } \\
2000 \text {, per capita }\end{array}$ & & $\begin{array}{l}.007 \\
(.004)\end{array}$ & & & $\begin{array}{l}2.620 * * * \\
(.643)\end{array}$ & \\
\hline Oil/GDP ratio & & & $\begin{array}{c}.123 * * * \\
(.029)\end{array}$ & & & $\begin{array}{l}.834 * * \\
(.367)\end{array}$ \\
\hline Capital-Labor ratio & & $\begin{array}{l}.691 * * * \\
(.047)\end{array}$ & & $\begin{array}{c}.711 * * * \\
(.046)\end{array}$ & & $\begin{array}{c}.692 * * * \\
(.046)\end{array}$ \\
\hline Absolute latitude & $\begin{array}{c}.014^{* * * *} \\
(.003)\end{array}$ & $\begin{array}{l}.001 \\
(.002)\end{array}$ & $\begin{array}{c}.014 * * * \\
(.003)\end{array}$ & $\begin{array}{l}.001 \\
(.002)\end{array}$ & $\begin{array}{c}.013 * * * \\
(.003)\end{array}$ & $\begin{array}{l}.001 \\
(.002)\end{array}$ \\
\hline European population & $\begin{array}{l}.474 * * * \\
(.133)\end{array}$ & $\begin{array}{l}.049 \\
(.070)\end{array}$ & $\begin{array}{l}.511 * * * \\
(.127)\end{array}$ & $\begin{array}{l}.064 \\
(.075)\end{array}$ & $\begin{array}{c}.613 * * * \\
(.130)\end{array}$ & $\begin{array}{l}.112 \\
(.082)\end{array}$ \\
\hline Latin America & $\begin{array}{l}.400 * * * \\
(.070)\end{array}$ & $\begin{array}{l}.052 \\
(.054)\end{array}$ & $\begin{array}{l}.365^{* * *} \\
(.064)\end{array}$ & $\begin{array}{l}.061 \\
(.053)\end{array}$ & $\begin{array}{l}.441^{* * *} \\
(.064)\end{array}$ & $\begin{array}{l}.093 * \\
(.052)\end{array}$ \\
\hline East Asia & $\begin{array}{l}.569^{* * *} \\
(.169)\end{array}$ & $\begin{array}{l}.015 \\
(.061)\end{array}$ & $\begin{array}{c}.547 * * * \\
(.162)\end{array}$ & $\begin{array}{l}.007 \\
(.057)\end{array}$ & $\begin{array}{l}.650^{* * * *} \\
(.146)\end{array}$ & $\begin{array}{l}.053 \\
(.058)\end{array}$ \\
\hline Observations & 109 & 109 & 124 & 124 & 124 & 124 \\
\hline Adj. $\mathrm{R}^{2}$ & .629 & .893 & .619 & .871 & .633 & .876 \\
\hline
\end{tabular}

Notes: Robust standard errors are in parentheses; constant is not shown; *** $\mathrm{p}<.01$, ** $\mathrm{p}<.05, * \mathrm{p}<.1$.

Results are presented in $<$ Table $3>$. When capital-labor ratio is included in the regression, a strongly positive impact of capital stock on the GDP level is evident. However, positive coefficients of resource measures in regressions with capital stock drop to approximately $1 / 3$ levels of coefficients without capital-labor ratio. Although impact of resource endowments on the economy weakens, the positive relation does not disappear. Moreover, one of correlation coefficients remains to be statistically significant at 5\% level.

As it is shown at $<$ Table $4>$, when institutional quality is controlled by running IV regression, statistically significant and stronger coefficients than those of the OLS regression are obtained. Inclusion of capital-labor ratio renders coefficients of 
almost all other variables insignificant. In this sense, positive impact of natural resource abundance on the economy can be confirmed, even with the capital stock in the regression.

〈Table 4〉 Effect of Capital Stock on Per Capita GDP by PWT II [IV] Dependent variable: Logarithm of per capita PPP GDP in 2000 by PWT

\begin{tabular}{|c|c|c|c|c|c|c|}
\hline Variable & {$[1]$} & [2] & [3] & [4] & [5] & [6] \\
\hline $\begin{array}{l}\text { Hydrocarbon deposits, } \\
\text { per capita }\end{array}$ & $\begin{array}{l}.024 * * * \\
(.005)\end{array}$ & & & $\begin{array}{l}.033 * * \\
(.014)\end{array}$ & & \\
\hline $\begin{array}{l}\text { Value of oil output in } \\
2000 \text {, per capita }\end{array}$ & & $\begin{array}{c}.009^{* * * *} \\
(.003)\end{array}$ & & & $\begin{array}{l}2.013 * * * \\
(.355)\end{array}$ & \\
\hline Oil/GDP ratio & & & $\begin{array}{c}.104 * * * \\
(.020)\end{array}$ & & & $\begin{array}{c}.931 * * * \\
(.271)\end{array}$ \\
\hline Capital-Labor ratio & & $\begin{array}{l}.581^{* * *} \\
(.115)\end{array}$ & & $\begin{array}{c}.612 * * * \\
(.121)\end{array}$ & & $\begin{array}{c}.588^{* * * *} \\
(.114)\end{array}$ \\
\hline Absolute latitude & $\begin{array}{c}-.245^{* * *} \\
(.074)\end{array}$ & $\begin{array}{l}-.056 \\
(.062)\end{array}$ & $\begin{array}{l}-.218 * * * \\
(.076)\end{array}$ & $\begin{array}{l}.009 \\
(.070)\end{array}$ & $\begin{array}{l}-.199 * * * \\
(.074)\end{array}$ & $\begin{array}{l}.006 \\
(.066)\end{array}$ \\
\hline European population & $\begin{array}{l}.061 \\
(.119)\end{array}$ & $\begin{array}{l}-.010 \\
(.081)\end{array}$ & $\begin{array}{l}.136 \\
(.125)\end{array}$ & $\begin{array}{l}.026 \\
(.083)\end{array}$ & $\begin{array}{l}.179 \\
(.131)\end{array}$ & $\begin{array}{l}.066 \\
(.090)\end{array}$ \\
\hline Latin America & $\begin{array}{l}.316^{* * *} \\
(.053)\end{array}$ & $\begin{array}{l}.087 \\
(.067)\end{array}$ & $\begin{array}{l}.310^{* * *} \\
(.048)\end{array}$ & $\begin{array}{l}.098 \\
(.069)\end{array}$ & $\begin{array}{c}.371 * * * \\
(.052)\end{array}$ & $\begin{array}{l}.135^{* *} \\
(.067)\end{array}$ \\
\hline East Asia & $\begin{array}{l}.209^{* * * *} \\
(.073)\end{array}$ & $\begin{array}{l}.006 \\
(.046)\end{array}$ & $\begin{array}{c}.212 * * * \\
(.076)\end{array}$ & $\begin{array}{l}.003 \\
(.048)\end{array}$ & $\begin{array}{c}.286^{* * * *} \\
(.078)\end{array}$ & $\begin{array}{l}.051 \\
(.050)\end{array}$ \\
\hline $\begin{array}{l}\text { Rule of law } \\
\text { (Instrumented) }\end{array}$ & $\begin{array}{c}.406^{* * *} \\
(.058)\end{array}$ & $\begin{array}{l}.111 \\
(.105)\end{array}$ & $\begin{array}{c}.391 * * * \\
(.061)\end{array}$ & $\begin{array}{l}.100 \\
(.105)\end{array}$ & $\begin{array}{c}.400^{* * *} \\
(.061)\end{array}$ & $\begin{array}{l}.108 \\
(.104)\end{array}$ \\
\hline Observations & 109 & 109 & 124 & 124 & 124 & 124 \\
\hline $\begin{array}{l}\text { P-value for } \\
\text { Hansen J stat. }\end{array}$ & .862 & .151 & .554 & .688 & .453 & .123 \\
\hline Adj. $\mathrm{R}^{2}$ & .823 & .916 & .813 & .892 & .813 & .899 \\
\hline
\end{tabular}

Notes: Robust standard errors are in parentheses; constant is not shown; *** $\mathrm{p}<.01$, ** $\mathrm{p}<.05, * \mathrm{p}<.1$. Instruments for rule of law: absolute latitude, English language speakers, European language speakers.

\section{Interaction Term between Resource and Institutional Quality}

Mehlum et al. (2006) and other literature claimed that influence of natural 
resources on economic growth depends on quality of institutions. They argued that nations with good institutions are predisposed to maximize their natural resources while those with bad institutions are supposed to suffer from the curse of natural resources. To analyze this argument, Alexeev and Conrad (2009) employed an interactive term between the quality of institutions and natural resources, concluding that countries with good institutions are likely to benefit less from the positive effect of natural resources while those with bad institutions tend to benefit more from the natural resources. This study follows their approach and tests the robustness of their results.

Results of the present study are presented in <Table 5>. In all regressions, coefficients of interactive terms are strongly negative. In six out of eight regressions, coefficients of interactive terms are significant at $1 \%$ level and other coefficients in two regressions, [3] and [4], using oil output as its resource measure are significant at 5\% level at regressions. Moreover, absolute coefficients of the interactive terms are greater than those of direct terms in all regressions, except for one regression using oil output, that is, [3]. As the rule of law index is measured in units ranging from about -2.5 to 2.5 , with higher values corresponding to better governance outcome and the index is centered around zero, the current results indicate that the large importance of interaction term and support that countries with relatively bad institutions benefit more from natural resource endowments.

In regression [2], by using oil reserve and all exogenous variables, the direct effect of natural resource on GDP is .057 while coefficient of the interactive term is -.1. For example, if a country with relatively weak institutions is evaluated as having -1 as its rule of law index, the total effect of natural resource on GDP will be approximately .157. Meanwhile, if a country with relatively good institutions is evaluated to have one as its rule of law index, the total effect will be approximately -.43. This result is significantly stronger than the findings of Alexeev and Conrad (2009). 
〈Table 5〉 Effect of Interaction Between Institutions and Natural Resources on Per Capita GDP

Dependent variable: Logarithm of per capita PPP GDP in 2006

\begin{tabular}{|c|c|c|c|c|c|c|c|c|}
\hline Variable & [1] & [2] & [3] & [4] & [5] & [6] & [7] & [8] \\
\hline $\begin{array}{l}\text { Oil reserve, } \\
\text { per capita }\end{array}$ & $\begin{array}{c}.086^{* * * *} \\
(.024)\end{array}$ & $\begin{array}{l}.057 * * \\
(.024)\end{array}$ & & & & & & \\
\hline $\begin{array}{c}\text { Value of oil output, } \\
\text { per capita }\end{array}$ & & & $\begin{array}{c}.094 * * * \\
(.022)\end{array}$ & $\begin{array}{c}.071 * * * \\
(.022)\end{array}$ & & & & \\
\hline $\begin{array}{c}\text { Natural gas reserve, } \\
\text { per capita }\end{array}$ & & & & & $\begin{array}{l}.033 * * \\
(.013)\end{array}$ & $\begin{array}{l}.019 \\
(.013)\end{array}$ & & \\
\hline $\begin{array}{l}\text { Value of natural gas } \\
\text { output, per capita }\end{array}$ & & & & & & & $\begin{array}{l}.025 * * \\
(.010)\end{array}$ & $\begin{array}{l}.015 \\
(.010)\end{array}$ \\
\hline $\begin{array}{l}\text { Rule of law } \\
\text { (fitted values) }\end{array}$ & $\begin{array}{c}.439 * * * \\
(.128)\end{array}$ & $\begin{array}{c}.367 * * * \\
(.122)\end{array}$ & $\begin{array}{c}.441 * * * \\
(.133)\end{array}$ & $\begin{array}{c}.374 * * * \\
(.132)\end{array}$ & $\begin{array}{c}.632 * * * \\
(.145)\end{array}$ & $\begin{array}{l}.513^{* * *} \\
(.143)\end{array}$ & $\begin{array}{c}.740 * * * \\
(.150)\end{array}$ & $\begin{array}{c}.610 * * * \\
(.159)\end{array}$ \\
\hline $\begin{array}{c}\text { (Rule of law) } \\
\text { *Natural resources }\end{array}$ & $\begin{array}{c}-.107 * * * \\
(.033)\end{array}$ & $\begin{array}{c}-.100 * * * \\
(.034)\end{array}$ & $\begin{array}{l}-.085^{* *} \\
(.032)\end{array}$ & $\begin{array}{c}-.079 * * \\
(.034)\end{array}$ & $\begin{array}{c}-.086 * * * \\
(.024)\end{array}$ & $\begin{array}{l}-.071 * * * \\
(.025)\end{array}$ & $\begin{array}{c}-.073 * * * \\
(.017)\end{array}$ & $\begin{array}{c}-.060^{* * *} \\
(.019)\end{array}$ \\
\hline Absolute latitude & $\begin{array}{l}.003 \\
(.004)\end{array}$ & $\begin{array}{l}.006 \\
(.004)\end{array}$ & $\begin{array}{l}.003 \\
(.004)\end{array}$ & $\begin{array}{l}.005 \\
(.004)\end{array}$ & $\begin{array}{l}-.000 \\
(.004)\end{array}$ & $\begin{array}{l}.003 \\
(.004)\end{array}$ & $\begin{array}{l}-.005 \\
(.004)\end{array}$ & $\begin{array}{l}-.000 \\
(.004)\end{array}$ \\
\hline ELF & $\begin{array}{l}-.098 \\
(.110)\end{array}$ & $\begin{array}{l}-.013 \\
(.111)\end{array}$ & $\begin{array}{l}-.118 \\
(.105)\end{array}$ & $\begin{array}{l}-.041 \\
(.107)\end{array}$ & $\begin{array}{l}-.108 \\
(.116)\end{array}$ & $\begin{array}{l}-.024 \\
(.117)\end{array}$ & $\begin{array}{l}-.159 \\
(.116)\end{array}$ & $\begin{array}{l}-.081 \\
(.121)\end{array}$ \\
\hline European population & $\begin{array}{c}.407 * * * \\
(.091)\end{array}$ & $\begin{array}{c}.304^{* * *} \\
(.086)\end{array}$ & $\begin{array}{l}.391 * * * \\
(.087)\end{array}$ & $\begin{array}{c}.298 * * * \\
(.084)\end{array}$ & $\begin{array}{c}.395^{* * *} \\
(.088)\end{array}$ & $\begin{array}{c}.295^{* * *} \\
(.083)\end{array}$ & $\begin{array}{c}.397 * * * \\
(.088)\end{array}$ & $\begin{array}{c}.300^{* * *} \\
(.084)\end{array}$ \\
\hline Latin America & $\begin{array}{c}.219 * * * \\
(.082)\end{array}$ & $\begin{array}{l}.103 \\
(.088)\end{array}$ & $\begin{array}{l}.204 * * \\
(.081)\end{array}$ & $\begin{array}{l}.104 \\
(.085)\end{array}$ & $\begin{array}{l}.195 * * \\
(.085)\end{array}$ & $\begin{array}{l}.075 \\
(.090)\end{array}$ & $\begin{array}{l}.120 \\
(.088)\end{array}$ & $\begin{array}{l}.045 \\
(.090)\end{array}$ \\
\hline East Asia & $\begin{array}{c}.683 * * * \\
(.127)\end{array}$ & $\begin{array}{c}.527 * * * \\
(.121)\end{array}$ & $\begin{array}{l}.583 * * * \\
(.111)\end{array}$ & $\begin{array}{c}.464^{* * * *} \\
(.110)\end{array}$ & $\begin{array}{c}.601 * * * \\
(.145)\end{array}$ & $\begin{array}{c}.459 * * * \\
(.130)\end{array}$ & $\begin{array}{c}.505^{* * *} \\
(.152)\end{array}$ & $\begin{array}{c}.416^{* * *} \\
(.135)\end{array}$ \\
\hline Africa & & $\begin{array}{c}-.199 * * \\
(.098)\end{array}$ & & $\begin{array}{l}-.179^{*} \\
(.097)\end{array}$ & & $\begin{array}{c}-.213^{* *} \\
(.100)\end{array}$ & & $\begin{array}{l}-.158 \\
(.106)\end{array}$ \\
\hline Landlocked & & $\begin{array}{c}-.139 * * \\
(.069)\end{array}$ & & $\begin{array}{l}-.111 \\
(.070)\end{array}$ & & $\begin{array}{l}-.135^{*} \\
(.070)\end{array}$ & & $\begin{array}{l}-.135^{*} \\
(.068)\end{array}$ \\
\hline Communist, former & & $\begin{array}{c}-.233 * * * \\
(.064)\end{array}$ & & $\begin{array}{c}-.231 * * * \\
(.064)\end{array}$ & & $\begin{array}{c}-.235 * * * * \\
(.063)\end{array}$ & & $\begin{array}{c}-.222 * * * \\
(.065)\end{array}$ \\
\hline Obervations & 151 & 151 & 151 & 151 & 151 & 151 & 151 & 151 \\
\hline Adj. $\mathrm{R}^{2}$ & .639 & .675 & .657 & .687 & .626 & .663 & .642 & .670 \\
\hline
\end{tabular}

Notes: The interactive term (Rule of law) $\times$ (Natural resources) is the product of the fitted value of rule of law index and natural resource measure that is used in the given regression. Robust standard errors are in parentheses; constant is not shown. ${ }^{* * *} \mathrm{p}<.01,{ }^{* *} \mathrm{p}<.05,{ }^{*} \mathrm{p}<.1$.

Needless to say, this result cannot be interpreted to imply that countries with good institutions tend to suffer from abundant natural resources. Instead, it is concluded 
that nations with weak institutions benefit significantly from their natural resource endowments while those with good institutions benefit less from these. This finding is believed to be derived as the former effect dominates the latter phenomenon.

\section{Natural Resources and Institutions}

\section{Estimation Approach and Data}

Some literature in favor for the resource curse ${ }^{6}$ claimed that natural resource endowments pose a negative effect on the quality of institutions. However, Alexeev and Conrad (2009) claimed that those arguments are derived by incorrect use of per capita GDP as a control variable. Their logic is that given positive correlations between natural resources and GDP and between institutions and GDP, inclusion of GDP as a control variable in the institutional quality regression misleads to the negative influence of natural resources on GDP. Instead of using the "initial" GDP, they generated the values of per capita GDP which a country can be predicted to have in the absence of natural resource endowments. They accomplished this by regressing logarithm of per capita GDP on the "strongly" exogenous variables with the following regression:

$$
Y_{i, 1970}=\beta_{0}+\sum \beta_{i} X_{i}+\epsilon_{i}
$$

where independent variables, $X_{i}$, are absolute value of latitude and the dummies for European population, Latin America, and East Asia. Subsequently, they compare the result of the following two institutional quality regressions that utilize $Y_{i, 1970}$ and $\hat{Y}_{i, 1970}$ :

6) For an overview of the resource curse, refer to Torvik (2009). It explains the variations in experiences among resource-abundant countries and discusses the theories of the resource curse. 


$$
\begin{aligned}
& I Q_{i}=\delta_{0}+\sum \delta_{i} X_{i}+\theta_{1} Y_{i, 1970}+\theta_{2} N_{i}+v_{i} \\
& I Q_{i}=\delta_{0}+\sum \delta_{i} X_{i}+\theta_{1} \hat{Y}_{i, 1970}+\theta_{2} N_{i}+v_{i}
\end{aligned}
$$

where IQ implies the rule of law index. In Alexeev and Conrad's estimation, coefficients of oil wealth in equation (4) are statistically insignificant and less than those of equation (3) in absolute value. With this result, they concluded that statistically significant negative correlations between oil wealth and institutional quality in previous literature are largely a result of the positive relation between GDP and oil, rather than the negative effect of oil endowments on institutions.

This methodology is followed in the present study. However, Alexeev and Conrad's set of exogenous variables used for deriving "predicted" per capita GDP is deemed too narrow. Robustness of their result is thus tested with both their set of variables and the present study's set of exogenous variables, which are composed of absolute value of latitude and dummies for European population, Latin America, sub-Saharan Africa, and landlockedness. The present study's set of exogenous variables does not include the dummy variable for East Asia as its coefficient becomes very insignificant under the present set of variables ${ }^{7}$. Upon inclusion of the FSU countries in the set of data, the basis year was chosen to be 1973 (i.e., this is the only year when the per capita GDP data of these countries, prior to 1989, was obtained, as prescribed by Maddison's study [2008]). Using pre-1989 data for the FSU countries may be controversial, but estimates by Maddison (2008) are the most appropriate data available for this study. To analyze robustness of the regression, other variables like share of protestant population and a dummy variable for the (former) communist economy have been included in the regression.

7) A regression is likewise run using predicted GDP with East Asia dummy; the inclusion is not reported as it does not affect the results. 


\section{Results}

With the same set of exogenous variables employed by Alexeev and Conrad (2009), the following estimation (robust standard errors are in parentheses) is derived:

$$
\begin{aligned}
& \hat{Y}_{i, 1973}=2.98+.014 \cdot \mathrm{LAT}+.3 \cdot \mathrm{EU}+.31 \cdot \mathrm{LATIN}+.2 \cdot \mathrm{EAST} \\
& \begin{array}{llll}
(.055) & (.002) & (.074)
\end{array}
\end{aligned}
$$

Adjusted $R^{2}=.453 ;$ No. obs. $=151$

Using this predicted value of GDP ("predicted 1" in the tables), very similar results to those of Alexeev and Conrad (2009) are obtained. Results are presented in $<$ Tables 6 to $9>$ according to the measure of natural resources. While all coefficients between rule of law index in 2007 and measures of natural resources in equation (3) using $Y_{i, 1973}$ are strongly negative and significant at $1 \%$ level (regressions [1] and [2] in <Tables 6 to $9>$ ), the same coefficients in equation (4) using $\hat{Y}_{i, 1973}$ are statistically insignificant and occasionally positive (regressions [3] and [4]). In every case, the point estimate of natural resource endowments in equation (4) is less than in equation (3) in absolute value.

In contrast with the findings above, different results were obtained with the present set of exogenous variables, composed of absolute value of latitude and dummies for European population, Latin America, sub-Saharan Africa, and landlockedness. With this new set of exogenous variables, the following estimation is derived (robust standard errors are in parentheses):

$$
\begin{array}{r}
\hat{Y}_{i, 1973}=3.25+.01 \cdot \mathrm{LAT}+.27 \cdot \mathrm{EU}+.14 \cdot \mathrm{LATIN}-.25 \bullet \mathrm{AFRICA}-.23 \cdot \mathrm{LAND} \\
(.095) \quad(.002) \quad(.074) \quad(.085) \\
\text { Adjusted } R^{2}=.53 ; \text { No. obs. }=151
\end{array}
$$


〈Table 6〉 Effect of Oil on Rule of Law I

Dependent variable: Rule of law index for year 2006

\begin{tabular}{|c|c|c|c|c|c|c|}
\hline Variable & [1] & {$[2]$} & [3] & [4] & [5] & [6] \\
\hline Oil reserve, per capita & $\begin{array}{c}-.250 * * * \\
(.058)\end{array}$ & $\begin{array}{c}-.206 * * * \\
(.052)\end{array}$ & $\begin{array}{l}-.039 \\
(.062)\end{array}$ & $\begin{array}{l}-.039 \\
(.054)\end{array}$ & $\begin{array}{l}-.112^{*} \\
(.064)\end{array}$ & $\begin{array}{l}-.096^{*} \\
(.055)\end{array}$ \\
\hline $\begin{array}{c}\text { GDP 1973, per capita } \\
\text { (actual) }\end{array}$ & $\begin{array}{c}1.445^{* * *} \\
(.191)\end{array}$ & $\begin{array}{c}1.160 * * * \\
(.197)\end{array}$ & & & & \\
\hline $\begin{array}{l}\text { GDP 1973, per capita } \\
\text { (predicted 1) }\end{array}$ & & & $\begin{array}{l}3.024 * * * \\
(.709)\end{array}$ & $\begin{array}{c}2.067 * * * \\
(.635)\end{array}$ & & \\
\hline $\begin{array}{l}\text { GDP 1973, per capita } \\
\text { (predicted 2) }\end{array}$ & & & & & $\begin{array}{c}1.593 * * * \\
(.465)\end{array}$ & $\begin{array}{c}1.410^{* * *} \\
(.405)\end{array}$ \\
\hline Absolute latitude & $\begin{array}{l}.006 \\
(.006)\end{array}$ & $\begin{array}{c}.017 * * * \\
(.006)\end{array}$ & $\begin{array}{l}-.017 \\
(.013)\end{array}$ & $\begin{array}{l}.004 \\
(.012)\end{array}$ & $\begin{array}{l}.006 \\
(.009)\end{array}$ & $\begin{array}{l}.015 \\
(.009)\end{array}$ \\
\hline English speakers & $\begin{array}{c}.012 * * * \\
(.003)\end{array}$ & $\begin{array}{c}.008^{* * *} \\
(.002)\end{array}$ & $\begin{array}{c}.015^{* * *} \\
(.003)\end{array}$ & $\begin{array}{c}.009 * * * \\
(.003)\end{array}$ & $\begin{array}{c}.013 * * * \\
(.003)\end{array}$ & $\begin{array}{c}.007 * * * \\
(.003)\end{array}$ \\
\hline European language & $\begin{array}{l}-.001 \\
(.002)\end{array}$ & $\begin{array}{l}-.001 \\
(.002)\end{array}$ & $\begin{array}{l}-.004 \\
(.003)\end{array}$ & $\begin{array}{l}-.002 \\
(.002)\end{array}$ & $\begin{array}{l}.000 \\
(.003)\end{array}$ & $\begin{array}{l}-.000 \\
(.002)\end{array}$ \\
\hline ELF & $\begin{array}{l}-.245 \\
(.270)\end{array}$ & $\begin{array}{l}-.215 \\
(.249)\end{array}$ & $\begin{array}{l}.127 \\
(.285)\end{array}$ & $\begin{array}{l}.043 \\
(.266)\end{array}$ & $\begin{array}{l}.120 \\
(.299)\end{array}$ & $\begin{array}{l}.095 \\
(.269)\end{array}$ \\
\hline Protestant share & & $\begin{array}{c}.006^{* * *} \\
(.002)\end{array}$ & & $\begin{array}{c}.006^{* * *} \\
(.002)\end{array}$ & & $\begin{array}{c}.008 * * * \\
(.002)\end{array}$ \\
\hline Communist, former & & $\begin{array}{c}-.865 * * * \\
(.148)\end{array}$ & & $\begin{array}{c}-.930 * * * \\
(.149)\end{array}$ & & $\begin{array}{c}-.977 * * * \\
(.146)\end{array}$ \\
\hline Observations & 151 & 151 & 151 & 151 & 151 & 151 \\
\hline Adj. $R^{2}$ & .531 & .644 & .452 & .580 & .418 & .582 \\
\hline
\end{tabular}

Notes: Robust standard errors are in parentheses; constant is not shown; *** $\mathrm{p}<.01$, ** $\mathrm{p}<.05, * \mathrm{p}<.1$.

Results are presented in <Tables 6 to $9>$ as well. Using this predicted value of GDP ("predicted 2" in the tables), negative and statistically significant correlation coefficients between rule of law index and the reserves of natural resources are obtained (regressions [5] and [6]). These results are considerably different to those of Alexeev and Conrad (2009). According to the present regression results, it is 
seemingly difficult to reject the hypothesis that large endowments of natural resources have significant negative correlation with institutional quality measure.

〈Table 7〉 Effect of Oil on Rule of Law II

Dependent variable: Rule of law index for year 2006

\begin{tabular}{|c|c|c|c|c|c|c|}
\hline Variable & [1] & [2] & {$[3]$} & [4] & [5] & [6] \\
\hline $\begin{array}{c}\text { Value of oil output, per } \\
\text { capita }\end{array}$ & $\begin{array}{c}-.157 * * * \\
(.055)\end{array}$ & $\begin{array}{c}-.127 * * * \\
(.047)\end{array}$ & $\begin{array}{l}.013 \\
(.050)\end{array}$ & $\begin{array}{l}.007 \\
(.044)\end{array}$ & $\begin{array}{l}-.040 \\
(.053)\end{array}$ & $\begin{array}{l}-.041 \\
(.045)\end{array}$ \\
\hline $\begin{array}{c}\text { GDP 1973, per capita } \\
\text { (actual) }\end{array}$ & $\begin{array}{c}1.333 * * * \\
(.199)\end{array}$ & $\begin{array}{l}1.057 * * * \\
(.200)\end{array}$ & & & & \\
\hline $\begin{array}{l}\text { GDP 1973, per capita } \\
\text { (predicted 1) }\end{array}$ & & & $\begin{array}{c}3.067 * * * \\
(.716)\end{array}$ & $\begin{array}{l}2.110^{* * *} \\
(.645)\end{array}$ & & \\
\hline $\begin{array}{l}\text { GDP } 1973 \text {, per capita } \\
\text { (predicted 2) }\end{array}$ & & & & & $\begin{array}{c}1.481 * * * \\
(.478)\end{array}$ & $\begin{array}{c}1.339 * * * \\
(.411)\end{array}$ \\
\hline Absolute latitude & $\begin{array}{l}.009 \\
(.006)\end{array}$ & $\begin{array}{l}.019^{* * *} \\
(.007)\end{array}$ & $\begin{array}{l}-.018 \\
(.013)\end{array}$ & $\begin{array}{l}.003 \\
(.013)\end{array}$ & $\begin{array}{l}.007 \\
(.010)\end{array}$ & $\begin{array}{l}.016^{*} \\
(.009)\end{array}$ \\
\hline English speakers & $\begin{array}{c}.012 * * * \\
(.003)\end{array}$ & $\begin{array}{c}.007 * * * \\
(.002)\end{array}$ & $\begin{array}{c}.014 * * * \\
(.003)\end{array}$ & $\begin{array}{c}.009^{* * *} \\
(.003)\end{array}$ & $\begin{array}{l}.012 * * * \\
(.003)\end{array}$ & $\begin{array}{l}.007 * * \\
(.003)\end{array}$ \\
\hline European language & $\begin{array}{l}-.001 \\
(.002)\end{array}$ & $\begin{array}{l}-.000 \\
(.002)\end{array}$ & $\begin{array}{l}-.004 \\
(.003)\end{array}$ & $\begin{array}{l}-.002 \\
(.003)\end{array}$ & $\begin{array}{l}.000 \\
(.003)\end{array}$ & $\begin{array}{l}-.000 \\
(.002)\end{array}$ \\
\hline ELF & $\begin{array}{l}-.286 \\
(.275)\end{array}$ & $\begin{array}{l}-.258 \\
(.255)\end{array}$ & $\begin{array}{l}.114 \\
(.280)\end{array}$ & $\begin{array}{l}.028 \\
(.262)\end{array}$ & $\begin{array}{l}.066 \\
(.298)\end{array}$ & $\begin{array}{l}.052 \\
(.270)\end{array}$ \\
\hline Protestant share & & $\begin{array}{l}.007 * * * \\
(.002)\end{array}$ & & $\begin{array}{c}.006^{* * *} \\
(.002)\end{array}$ & & $\begin{array}{l}.008^{* * * *} \\
(.002)\end{array}$ \\
\hline Communist, former & & $\begin{array}{c}-.880 * * * \\
(.152)\end{array}$ & & $\begin{array}{c}-.922 * * * \\
(.151)\end{array}$ & & $\begin{array}{c}-.977 * * * \\
(.149)\end{array}$ \\
\hline Observations & 151 & 151 & 151 & 151 & 151 & 151 \\
\hline Adj. $\mathrm{R}^{2}$ & .494 & .619 & .450 & .578 & .404 & .572 \\
\hline
\end{tabular}

Notes: Robust standard errors are in parentheses; constant is not shown; *** $\mathrm{p}<.01$, ** $\mathrm{p}<.05, * \mathrm{p}<.1$. 
However, it is hasty to conclude that natural resource abundance negatively affects the quality of institutions, or that the result of Alexeev and Conrad (2009) is misleading since the present data is different from those of the previous literature in two major points. One is the inclusion of the former Soviet Union, and the other is the use of different measures of natural resources and/or different sources of GDP level. The rest of the paper will test whether results come from these differences.

〈Table 8〉 Effect of Natural Gas on Rule of Law I Dependent variable: Rule of law index for year 2006

\begin{tabular}{c|c|c|c|c|c|c}
\hline Variable & {$[1]$} & {$[2]$} & {$[3]$} & {$[4]$} & {$[5]$} & {$[6]$} \\
\hline capita & $(.034)$ & $(.030)$ & $(.033)$ & $(.029)$ & $(.037)$ & $(.031)$ \\
Natural gas reserve, per & $-.122^{* * *}$ & $-.088^{* * *}$ & -.032 & -.018 & $-.078^{* *}$ & $-.052^{*}$ \\
GDP 1973, per capita & $1.303^{* * *}$ & $1.014^{* * *}$ & & & & \\
GDP 1973, per capita & $(.178)$ & $(.188)$ & & & & \\
(predicted 1) & & & $3.024 * * *$ & $2.093^{* * *}$ & & \\
GDP 1973, per capita & & & $(.703)$ & $(.638)$ & & \\
(predicted 2) & & & & & $1.688^{* * *}$ & $1.430^{* * *}$ \\
Absolute latitude & .008 & $.019 * * *$ & -.017 & .004 & .005 & .015 \\
& $(.006)$ & $(.006)$ & $(.013)$ & $(.012)$ & $(.010)$ & $(.009)$ \\
English speakers & $.013^{* * *}$ & $.008^{* * *}$ & $.015^{* * *}$ & $.009^{* * *}$ & $.014 * * *$ & $.008^{* *}$ \\
& $(.003)$ & $(.003)$ & $(.003)$ & $(.003)$ & $(.003)$ & $(.003)$ \\
European language & -.001 & -.001 & -.004 & -.002 & -.000 & -.001 \\
& $(.002)$ & $(.002)$ & $(.003)$ & $(.003)$ & $(.003)$ & $(.002)$ \\
ELF & -.308 & -.264 & .118 & .035 & .112 & .076 \\
& $(.264)$ & $(.247)$ & $(.285)$ & $(.265)$ & $(.297)$ & $(.270)$ \\
Protestant share & & $.005^{* *}$ & & $.0066^{* * *}$ & & $.007 * * *$ \\
& & $(.002)$ & & $(.002)$ & & $(.002)$ \\
Communist, former & & $-.870^{* * *}$ & & $-.925^{* * *}$ & & $-.967 * * *$ \\
Adj. R ${ }^{2}$ & .515 & .625 & .454 & .579 & .424 & .580 \\
\hline Observations & 151 & 151 & 151 & 151 & 151 & 151 \\
\hline
\end{tabular}

Notes: Robust standard errors are in parentheses; constant is not shown; *** $\mathrm{p}<.01$, ** $\mathrm{p}<.05, * \mathrm{p}<.1$. 
〈Table 9〉 Effect of Natural Gas on Rule of Law II

Dependent variable: Rule of law index for year 2006

\begin{tabular}{c|c|c|c|c|c|c}
\hline Variable & {$[1]$} & {$[2]$} & {$[3]$} & {$[4]$} & {$[5]$} & {$[6]$} \\
\hline Value of natural gas & $-.064^{* * *}$ & $-.040^{*}$ & -.012 & -.000 & -.042 & -.022 \\
output, per capita & $(.024)$ & $(.022)$ & $(.023)$ & $(.020)$ & $(.026)$ & $(.022)$ \\
GDP 1973, per capita & $1.202^{* * *}$ & $.915^{* * *}$ & & & & \\
(actual) & $(.183)$ & $(.189)$ & & & & \\
GDP 1973, per capita & & & $3.065^{* * *}$ & $2.111^{* * *}$ & & \\
(predicted 1) & & & $(.713)$ & $(.647)$ & & \\
GDP 1973, per capita & & & & & $1.629 * * *$ & $1.349^{* * *}$ \\
(predicted 2) & & & & & $(.504)$ & $(.430)$ \\
Absolute latitude & $.011^{*}$ & $.022^{* * *}$ & -.018 & .003 & .006 & $.016^{*}$ \\
& $(.006)$ & $(.006)$ & $(.013)$ & $(.012)$ & $(.010)$ & $(.009)$ \\
English speakers & $.013^{* * *}$ & $.008^{* * *}$ & $.015^{* * *}$ & $.009^{* * *}$ & $.013 * * *$ & $.007 * *$ \\
& $(.003)$ & $(.003)$ & $(.003)$ & $(.003)$ & $(.003)$ & $(.003)$ \\
European language & -.000 & -.000 & -.004 & -.002 & .000 & -.000 \\
& $(.002)$ & $(.002)$ & $(.003)$ & $(.003)$ & $(.003)$ & $(.002)$ \\
ELF & -.298 & -.256 & .122 & .031 & .103 & .059 \\
& $(.274)$ & $(.253)$ & $(.284)$ & $(.262)$ & $(.301)$ & $(.270)$ \\
Protestant share & & $.005^{* *}$ & & $.0066^{* * *}$ & & $.007 * * *$ \\
& & $(.002)$ & & $(.002)$ & & $(.002)$ \\
Communist, former & & $-.902^{* * *}$ & & $-.923 * * *$ & & $-.979^{* * *}$ \\
Observations & 151 & 151 & 151 & 151 & 151 & 151 \\
Adj. R ${ }^{2}$ & .491 & .609 & .451 & .578 & .413 & .573 \\
\hline
\end{tabular}

Notes: Robust standard errors are in parentheses; constant is not shown; *** $\mathrm{p}<.01, * *$ $\mathrm{p}<.05, * \mathrm{p}<.1$.

\section{Effect of the Former Soviet Union}

One of the major differences between previous literature on the natural resource curse and the present research is the inclusion of the FSU countries. To examine the effect of this inclusion on results, regressions are run without the FSU countries. The regression results for the relationship between natural resources and GDP change little without the FSU. That is, the positive impact of natural resource 
abundance on the economy is confirmed without the FSU8). Instead, focus is placed on the effect of natural resources on institutional quality. In the absence of FSU in the present data set, predicted value of GDP must be recalculated.

With the same set of exogenous variable employed by Alexeev and Conrad (2009), the following estimation is derived (robust standard errors are in parentheses):

$$
\begin{aligned}
& \hat{Y}_{i, 1973}=3.01+.011 \cdot \mathrm{LAT}+.42 \cdot \mathrm{EU}+.33 \cdot \mathrm{LATIN}+.23 \cdot \mathrm{EAST} \\
& \text { (.057) (.003) (.125) (.071) } \\
& \text { Adjusted } R^{2}=.44 \text {; No. obs. }=136
\end{aligned}
$$

With the present set of exogenous variables, the following estimation result is obtained (robust standard errors are in parentheses):

$$
\begin{aligned}
& \hat{Y}_{i, 1973}=3.29+.065 \cdot \mathrm{LAT}+.38 \cdot \mathrm{EU}+.15 \bullet \mathrm{LATIN}-.24 \bullet \mathrm{AFRICA}-.26 \bullet \mathrm{LAND} \\
& \begin{array}{llll}
(.092) \quad(.003) \quad(.115) \quad(.087) \quad(.083) \quad(.064)
\end{array} \\
& \text { Adjusted } R^{2}=.52 \text {; No. obs. }=136
\end{aligned}
$$

Using these predicted values of GDP (termed "predicted 1" and "predicted 2" in the tables, respectively), interesting results are obtained. Results are presented in $<$ Tables 10 to $13>$ according to the measure of natural resources. Note that all coefficients between rule of law index and measures of natural resources in equation (3) using $Y_{i, 1973}$ are strongly negative and all except one result are statistically significant (regressions [1] and [2] in the tables). On the other hand, all coefficients in equation (4) using $\hat{Y}_{i, 1973}$ are statistically insignificant, and a number of them are positive (regressions [3] and [4] in the tables). Unlike the previous section, negative and statistically significant coefficients between rule of

8) The detailed result is not presented in this article. 
law index and resource measures are no longer obtained using "predicted 2" GDP (regressions [5] and [6] in the tables).

〈Table 10〉 Effect of Oil on Rule of Law without the FSU I Dependent variable: Rule of law index for year 2006

\begin{tabular}{|c|c|c|c|c|c|c|}
\hline Variable & [1] & [2] & [3] & [4] & [5] & [6] \\
\hline Oil reserve, per capita & $\begin{array}{c}-.224 * * * \\
(.057)\end{array}$ & $\begin{array}{c}-.204 * * * \\
(.057)\end{array}$ & $\begin{array}{l}-.007 \\
(.060)\end{array}$ & $\begin{array}{l}-.015 \\
(.056)\end{array}$ & $\begin{array}{l}-.057 \\
(.061)\end{array}$ & $\begin{array}{l}-.066 \\
(.059)\end{array}$ \\
\hline $\begin{array}{c}\text { GDP 1973, per capita } \\
\text { (actual) }\end{array}$ & $\begin{array}{c}1.419 * * * \\
(.191)\end{array}$ & $\begin{array}{c}1.260 * * * \\
(.198)\end{array}$ & & & & \\
\hline $\begin{array}{l}\text { GDP 1973, per capita } \\
\text { (predicted 1) }\end{array}$ & & & $\begin{array}{l}1.704 * * * \\
(.637)\end{array}$ & $\begin{array}{l}1.661 * * * \\
(.571)\end{array}$ & & \\
\hline $\begin{array}{l}\text { GDP } 1973 \text {, per capita } \\
\text { (predicted 2) }\end{array}$ & & & & & $\begin{array}{c}1.050 * * \\
(.423)\end{array}$ & $\begin{array}{c}1.153 * * * \\
(.385)\end{array}$ \\
\hline Absolute latitude & $\begin{array}{c}.020 * * * \\
(.007)\end{array}$ & $\begin{array}{c}.022^{* * *} \\
(.007)\end{array}$ & $\begin{array}{l}.016 \\
(.013)\end{array}$ & $\begin{array}{l}.016 \\
(.012)\end{array}$ & $\begin{array}{c}.028^{* * *} \\
(.010)\end{array}$ & $\begin{array}{l}.024 * * \\
(.009)\end{array}$ \\
\hline English speakers & $\begin{array}{c}.009 * * * \\
(.002)\end{array}$ & $\begin{array}{c}.008^{* * *} * \\
(.002)\end{array}$ & $\begin{array}{c}.011 * * * \\
(.003)\end{array}$ & $\begin{array}{c}.008 * * * \\
(.003)\end{array}$ & $\begin{array}{c}.009 * * * \\
(.003)\end{array}$ & $\begin{array}{l}.007 * * \\
(.003)\end{array}$ \\
\hline European language & $\begin{array}{l}-.002 \\
(.002)\end{array}$ & $\begin{array}{l}-.002 \\
(.002)\end{array}$ & $\begin{array}{l}-.002 \\
(.003)\end{array}$ & $\begin{array}{l}-.002 \\
(.002)\end{array}$ & $\begin{array}{l}.000 \\
(.002)\end{array}$ & $\begin{array}{l}-.000 \\
(.002)\end{array}$ \\
\hline ELF & $\begin{array}{l}.161 \\
(.257)\end{array}$ & $\begin{array}{l}.044 \\
(.260)\end{array}$ & $\begin{array}{l}.304 \\
(.285)\end{array}$ & $\begin{array}{l}.132 \\
(.286)\end{array}$ & $\begin{array}{l}.382 \\
(.289)\end{array}$ & $\begin{array}{l}.209 \\
(.289)\end{array}$ \\
\hline Protestant share & & $\begin{array}{l}.003 \\
(.002)\end{array}$ & & $\begin{array}{l}.004^{*} \\
(.002)\end{array}$ & & $\begin{array}{l}.006^{* *} \\
(.002)\end{array}$ \\
\hline Communist, former & & $\begin{array}{c}-.478 * * * \\
(.165) \\
\end{array}$ & & $\begin{array}{c}-.799 * * * \\
(.175)\end{array}$ & & $\begin{array}{c}-.789 * * * \\
(.172)\end{array}$ \\
\hline Observations & 136 & 136 & 136 & 136 & 136 & 136 \\
\hline Adj. $\mathrm{R}^{2}$ & .650 & .671 & .524 & .586 & .513 & .583 \\
\hline
\end{tabular}

Notes: Robust standard errors are in parentheses; constant is not shown; *** $\mathrm{p}<.01$, ** $\mathrm{p}<.05, * \mathrm{p}<.1$.

It is concluded that statistically significant and negative coefficients of the previous section mainly result from the inclusion of the FSU. It is speculated that this result is caused by economic and political transition of the FSU.

Since the collapse of the Soviet Union, a number of successors of the FSU have 
become considerably abundant in resources. According to BP (2008), proved oil reserves of the FSU jumped by $115 \%$ between 1987 and 2007 from 59.5 to 128.1 thousand million barrels. During the same period, proved natural gas reserves of the FSU likewise leaped by $38 \%$ from 38.9 to 53.53 trillion cubic meters. This sharp increase of oil and natural gas reserves is an unusual phenomenon compared to the other parts of the world. It is believed that following the collapse of the Soviet Union, the quick influx of western investment capital and advanced exploration technology boosted the estimated reserves of oil and natural gas.

〈Table 11〉 Effect of Oil on Rule of Law without the FSU II Dependent variable: Rule of law index for year 2006

\begin{tabular}{|c|c|c|c|c|c|c|}
\hline Variable & {$[1]$} & [2] & [3] & [4] & [5] & [6] \\
\hline $\begin{array}{c}\text { Value of oil output, per } \\
\text { capita }\end{array}$ & $\begin{array}{c}-.151^{* * * *} \\
(.050)\end{array}$ & $\begin{array}{l}-.132 * * * \\
(.050)\end{array}$ & $\begin{array}{l}.037 \\
(.048)\end{array}$ & $\begin{array}{l}.028 \\
(.046)\end{array}$ & $\begin{array}{l}.001 \\
(.049)\end{array}$ & $\begin{array}{l}-.012 \\
(.047)\end{array}$ \\
\hline $\begin{array}{l}\text { GDP 1973, per capita } \\
\text { (actual) }\end{array}$ & $\begin{array}{l}1.341^{* * *} \\
(.193)\end{array}$ & $\begin{array}{c}1.172^{* * *} \\
(.198)\end{array}$ & & & & \\
\hline $\begin{array}{l}\text { GDP } 1973 \text {, per capita } \\
\text { (predicted 1) }\end{array}$ & & & $\begin{array}{l}1.705^{* * *} \\
(.635)\end{array}$ & $\begin{array}{c}1.669 * * * \\
(.577)\end{array}$ & & \\
\hline $\begin{array}{l}\text { GDP } 1973 \text {, per capita } \\
\text { (predicted 2) }\end{array}$ & & & & & $\begin{array}{l}.951 * * \\
(.422)\end{array}$ & $\begin{array}{c}1.074 * * * \\
(.386)\end{array}$ \\
\hline Absolute latitude & $\begin{array}{c}.022 * * * \\
(.007)\end{array}$ & $\begin{array}{c}.024 * * * \\
(.007)\end{array}$ & $\begin{array}{l}.015 \\
(.013)\end{array}$ & $\begin{array}{l}.015 \\
(.012)\end{array}$ & $\begin{array}{c}.029 * * * \\
(.009)\end{array}$ & $\begin{array}{c}.025^{* * * *} \\
(.009)\end{array}$ \\
\hline English speakers & $\begin{array}{c}.009 * * * \\
(.003)\end{array}$ & $\begin{array}{c}.007 * * * \\
(.002)\end{array}$ & $\begin{array}{c}.010 * * * \\
(.003)\end{array}$ & $\begin{array}{c}.008 * * * \\
(.003)\end{array}$ & $\begin{array}{c}.009 * * * \\
(.003)\end{array}$ & $\begin{array}{l}.006^{* *} \\
(.003)\end{array}$ \\
\hline European language & $\begin{array}{l}-.002 \\
(.002)\end{array}$ & $\begin{array}{l}-.001 \\
(.002)\end{array}$ & $\begin{array}{l}-.002 \\
(.003)\end{array}$ & $\begin{array}{l}-.002 \\
(.002)\end{array}$ & $\begin{array}{l}.000 \\
(.002)\end{array}$ & $\begin{array}{l}-.000 \\
(.002)\end{array}$ \\
\hline ELF & $\begin{array}{l}.136 \\
(.263)\end{array}$ & $\begin{array}{l}.011 \\
(.266)\end{array}$ & $\begin{array}{l}.292 \\
(.280)\end{array}$ & $\begin{array}{l}.120 \\
(.282)\end{array}$ & $\begin{array}{l}.345 \\
(.289)\end{array}$ & $\begin{array}{l}.176 \\
(.289)\end{array}$ \\
\hline Protestant share & & $\begin{array}{l}.004 * \\
(.002)\end{array}$ & & $\begin{array}{l}.004 * \\
(.002)\end{array}$ & & $\begin{array}{l}.006 * * \\
(.002)\end{array}$ \\
\hline Communist, former & & $\begin{array}{c}-.490 * * * \\
(.169) \\
\end{array}$ & & $\begin{array}{c}-.788 * * * \\
(.174) \\
\end{array}$ & & $\begin{array}{c}-.777 * * * \\
(.172) \\
\end{array}$ \\
\hline Observations & 136 & 136 & 136 & 136 & 136 & 136 \\
\hline Adj. $\mathrm{R}^{2}$ & .625 & .648 & .526 & .587 & .509 & .577 \\
\hline
\end{tabular}

Notes: Robust standard errors are in parentheses; constant is not shown; *** $\mathrm{p}<.01$, ** $\mathrm{p}<.05, * \mathrm{p}<.1$. 
〈Table 12〉 Effect of Natural Gas on Rule of Law without the FSU I Dependent variable: Rule of law index for year 2006

\begin{tabular}{|c|c|c|c|c|c|c|}
\hline Variable & [1] & {$[2]$} & [3] & [4] & [5] & [6] \\
\hline $\begin{array}{l}\text { Natural gas reserve, per } \\
\text { capita }\end{array}$ & $\begin{array}{c}-.097 * * * \\
(.034)\end{array}$ & $\begin{array}{c}-.082 * * \\
(.034)\end{array}$ & $\begin{array}{l}-.002 \\
(.033)\end{array}$ & $\begin{array}{l}.003 \\
(.031)\end{array}$ & $\begin{array}{l}-.034 \\
(.036)\end{array}$ & $\begin{array}{l}-.029 \\
(.034)\end{array}$ \\
\hline $\begin{array}{c}\text { GDP 1973, per capita } \\
\text { (actual) }\end{array}$ & $\begin{array}{c}1.263 * * * \\
(.188)\end{array}$ & $\begin{array}{c}1.098 * * * \\
(.196)\end{array}$ & & & & \\
\hline $\begin{array}{l}\text { GDP 1973, per capita } \\
\text { (predicted 1) }\end{array}$ & & & $\begin{array}{c}1.709 * * * \\
(.633)\end{array}$ & $\begin{array}{c}1.677 * * * \\
(.571)\end{array}$ & & \\
\hline $\begin{array}{l}\text { GDP 1973, per capita } \\
\text { (predicted 2) }\end{array}$ & & & & & $\begin{array}{c}1.070^{* *} \\
(.450)\end{array}$ & $\begin{array}{c}1.140 * * * \\
(.407)\end{array}$ \\
\hline Absolute latitude & $\begin{array}{l}.023 * * * \\
(.006)\end{array}$ & $\begin{array}{l}.024 * * * \\
(.007)\end{array}$ & $\begin{array}{l}.015 \\
(.013)\end{array}$ & $\begin{array}{l}.015 \\
(.012)\end{array}$ & $\begin{array}{c}.027 * * * \\
(.010)\end{array}$ & $\begin{array}{l}.025^{* *} \\
(.010)\end{array}$ \\
\hline English speakers & $\begin{array}{c}.010 * * * \\
(.003)\end{array}$ & $\begin{array}{c}.008^{* * *} * \\
(.003)\end{array}$ & $\begin{array}{c}.011 * * * \\
(.003)\end{array}$ & $\begin{array}{c}.008 * * * \\
(.003)\end{array}$ & $\begin{array}{c}.010 * * * \\
(.003)\end{array}$ & $\begin{array}{l}.007 * * \\
(.003)\end{array}$ \\
\hline European language & $\begin{array}{l}-.002 \\
(.002)\end{array}$ & $\begin{array}{l}-.001 \\
(.002)\end{array}$ & $\begin{array}{l}-.002 \\
(.003)\end{array}$ & $\begin{array}{l}-.002 \\
(.002)\end{array}$ & $\begin{array}{l}.000 \\
(.002)\end{array}$ & $\begin{array}{l}-.000 \\
(.002)\end{array}$ \\
\hline ELF & $\begin{array}{l}.105 \\
(.256)\end{array}$ & $\begin{array}{l}-.004 \\
(.257)\end{array}$ & $\begin{array}{l}.303 \\
(.285)\end{array}$ & $\begin{array}{l}.127 \\
(.286)\end{array}$ & $\begin{array}{l}.370 \\
(.287)\end{array}$ & $\begin{array}{l}.191 \\
(.288)\end{array}$ \\
\hline Protestant share & & $\begin{array}{l}.003 \\
(.002)\end{array}$ & & $\begin{array}{l}.004^{*} \\
(.002)\end{array}$ & & $\begin{array}{l}.006 * * \\
(.002)\end{array}$ \\
\hline Communist, former & & $\begin{array}{c}-.488 * * * \\
(.168)\end{array}$ & & $\begin{array}{c}-.795 * * * \\
(.176)\end{array}$ & & $\begin{array}{c}-.778 * * * \\
(.173)\end{array}$ \\
\hline Observations & 136 & 136 & 136 & 136 & 136 & 136 \\
\hline Adj. $\mathrm{R}^{2}$ & .629 & .649 & .524 & .586 & .513 & .580 \\
\hline
\end{tabular}

Notes: Robust standard errors are in parentheses; constant is not shown; *** $\mathrm{p}<.01$, ** $\mathrm{p}<.05, * \mathrm{p}<.1$.

On the other hand, institutional quality of the FSU appears to be trapped in the past. Close examination of the change of the rule of law index from 1996 to 2007 will reveal that indices of the FSU countries remain at low conditions. For example, the index for Russia decreased slightly from -.73 to -.97; for Kazakhstan, it remained at -.83; and for Azerbaijan, it increased slightly from -.94 to -.83. It is believed that institutional quality of the FSU was initially estimated at its low status owing to the remnants of communism; quality remains at a bad level because 
of instability during the transition period. Collapse of the FSU is believed to have resulted in a natural resource windfall on the one hand and political and economic instability on the other hand. Should this speculation prove sound, FSU countries would be saddled with bad institutions regardless of their natural resources. In this scenario, a negative correlation coefficient may be obtained between institutional quality and the measure of natural resources. However, this result should be regarded not as a direct correlation but as a mere coincidence.

〈Table 13〉 Effect of Natural Gas on Rule of Law without the FSU II Dependent variable: Rule of law index for year 2006

\begin{tabular}{c|c|c|c|c|c|c}
\hline Variable & {$[1]$} & {$[2]$} & {$[3]$} & {$[4]$} & {$[5]$} & {$[6]$} \\
\hline Value of natural gas & $-.044^{*}$ & -.033 & .012 & .016 & -.008 & -.003 \\
output, per capita & $. .023)$ & $(.023)$ & $(.022)$ & $(.021)$ & $(.025)$ & $(.023)$ \\
GDP 1973, per capita & $1.161^{* * *}$ & $.990^{* * *}$ & & & & \\
(actual) & $.192)$ & $(.195)$ & & & & \\
GDP 1973, per capita & & & $1.716^{* * *}$ & $1.674^{* * *}$ & & \\
(predicted 1) & & & $(.637)$ & $(.580)$ & & \\
GDP 1973, per capita & & & & & $.993^{* *}$ & $1.058^{* * *}$ \\
(predicted 2) & & & & & $.448)$ & $(.402)$ \\
& $.025^{* * *}$ & $.027^{* * *}$ & .015 & .015 & $.028^{* * *}$ & $.026^{* * *}$ \\
Absolute latitude & $(.006)$ & $(.007)$ & $(.013)$ & $(.012)$ & $(.010)$ & $(.009)$ \\
& $.009^{* * *}$ & $.007 * *$ & $.010^{* * *}$ & $.008^{* *}$ & $.009^{* * *}$ & $.0066^{* *}$ \\
English speakers & $(.003)$ & $(.003)$ & $(.003)$ & $(.003)$ & $(.003)$ & $(.003)$ \\
& -.001 & -.001 & -.002 & -.002 & .000 & -.000 \\
European language & $(.002)$ & $(.002)$ & $(.003)$ & $(.002)$ & $(.002)$ & $(.002)$ \\
& .119 & -.000 & .299 & .117 & .356 & .172 \\
ELF & $(.264)$ & $(.262)$ & $(.282)$ & $(.280)$ & $(.287)$ & $(.286)$ \\
& & .003 & & $.004 * *$ & & $.006^{* *}$ \\
Protestant share & & $(.002)$ & & $(.002)$ & & $(.002)$ \\
& & $-.523^{* * *}$ & & $-.786^{* * *}$ & & $-.775^{* * *}$ \\
Communist, former & & $(.167)$ & & $(.176)$ & & $(.173)$ \\
\hline Observations & 136 & 136 & 136 & 136 & 136 & 136 \\
Adj. R ${ }^{2}$ & .611 & .635 & .525 & .587 & .509 & .577 \\
\hline
\end{tabular}

Notes: Robust standard errors are in parentheses; constant is not shown; *** $\mathrm{p}<.01, * *$ $\mathrm{p}<.05, * \mathrm{p}<.1$. 
Further, collapse of the FSU may have already led to the improvement of institutions at the early stage of transition and this improvement may lead to resource windfall. It is possible that the previous regime had such bad institutions that they prevented the resource windfall. Thus, certain improvements in institutions after the collapse may lead to windfall. Unfortunately, it is difficult to identify the extent of difference in institutional quality before and after the collapse of the FSU as World Bank institutional quality indicators were only made available in 1996. However, if the collapse of the FSU per se did imply improvement of institutional quality, then natural resource abundance in the region can be considered as a result of institutional advancement, not the root cause of bad institutions.

Numerous literature take natural resources as exogenous. However, resource endowments should not be treated as "manna from heaven." In this sense, it is extremely important to consider endogeneity of natural resources to institutions. It is hoped that future research would provide a better understanding of such endogeneity.

\section{Use of Different Resource Measures and GDP Data}

\section{Three Additional Combinations of Resource Measures and GDP}

Another difference between previous literature and the present research lies in the use of different resource measures and GDP data source. To assess the effect of this usage on results, regressions with resource measures and GDP data commonly used in previous literature are run.

There are two different sources of GDP per capita: Maddison (2008) and the Penn World Table (PWT) by Heston et al. (2006). The former is utilized in the present study and by Alexeev and Conrad (2009), while the latter source is commonly used in extant literature. Further, there are two different sets of resource 
measures. The set employed in this study includes per capita oil reserve, value of oil output, natural gas reserve, and value of natural gas output. The other set employed by Alexeev and Conrad (2009) and other literature includes hydrocarbon deposits, value of oil output in 2000, and oil/GDP ratio. Thus, there are three additional combinations of data sets: PWT and the measures in the present study; Maddison's and other measures; and PWT and other measures. However, the use of different resource measures and GDP data does not harm the results of this study.9)

\section{Averaged Measures of Resource and Institutional Quality}

The result obtained until now may originate from the selection of a specific year as basis year. As price of oil fluctuates annually and oil price in 1990s was relatively lower than that in 2000 s in $<$ Table $14>$, the selection of basis year for the resource measure may affect the regression result. This effect can be the case with the rule of law index. Thus, this study attempted to alleviate influence of basis year selection by dealing with averaged measures of natural resources and institutional quality.

Logarithm of per capita PPP GDP in 2000 from the PWT 6.2 by Heston et al. (2006) is employed as dependent variable. In addition to the three conventional measures - hydrocarbon deposits, value of oil output in 2000, and oil/GDP ratiotwo additional resource measures have been added as the averaged measure of natural resources: average oil reserve from 1996 to 2005 and average oil value from 1996 to 2005. Rule of law index in 2000 is likewise used as the benchmark and averaged rule of law index from 1996 to 2005 is employed as the averaged measure of institutional quality. Additionally, capital stock per worker is included in the regressions of natural resources on economic performance. However, the use of averaged measures led to little changes in the results. ${ }^{10}$ )

9) The detailed result is not presented in this paper. 
〈Table 14〉 Crude Oil Prices 1990 - 2007 (Unit: US dollars per barrel)

\begin{tabular}{c|c|c}
\hline Year & \$ money of the day & $\$ 2007$ \\
\hline 1990 & 23.73 & 37.82 \\
\hline 1991 & 20.00 & 30.57 \\
\hline 1992 & 19.32 & 28.65 \\
\hline 1993 & 16.97 & 24.52 \\
\hline 1994 & 15.82 & 22.37 \\
\hline 1995 & 17.02 & 23.40 \\
\hline 1996 & 20.67 & 27.54 \\
\hline 1997 & 19.09 & 24.97 \\
\hline 1998 & 12.72 & 16.69 \\
\hline 1999 & 17.97 & 22.74 \\
\hline 2000 & 28.50 & 34.92 \\
\hline 2001 & 24.44 & 29.03 \\
\hline 2002 & 25.02 & 29.06 \\
\hline 2003 & 28.83 & 32.51 \\
\hline 2004 & 38.27 & 42.02 \\
\hline 2005 & 54.52 & 57.90 \\
\hline 2006 & 65.14 & 67.03 \\
\hline 2007 & 72.39 & 72.39 \\
\hline
\end{tabular}

Source: BP (2008). Brent dated.

\section{Concluding Remarks}

Contrary to previous research on the curse of natural resources, this study has demonstrated that natural resources possess a strong positive correlation with a country's economy. This result is confirmed to be robust with broad sets of exogenous variables, and the positive impact of natural resources on the economy remains significant with the inclusion of capital stock per worker in the regression equations. If a country records a higher level of per capita GDP compared with

10) The detailed result is not presented in this paper. 
another country, the former should have experienced faster growth than the latter within a certain period of its prior growth path. In this sense, it is doubtful that resource curse actually exists.

On the other hand, this study tested whether the quality of institutions has any relation with natural resource endowments if the positive effect of natural resource endowments on GDP is adequately controlled for. In contrast with Alexeev and Conrad's (2009) findings, if the FSU countries are included in the sample, it seems that there may be a negative and statistically significant relationship between large endowments of natural resources and the quality of institutions. However, this negative relationship loses its significance and some positive albeit insignificant relationships are confirmed in a considerable number of cases when the FSU countries are excluded. That is, the negative relationship results from the inclusion of the FSU countries. This result is believed to happen by a temporary coincidence of events, a natural resource windfall and political and economic instability during the transition of the FSU countries. Therefore, the argument that resource abundance harms the institutional quality is confirmed to be a little groundless. Further, estimation results are robust under a wide set of exogenous variables, and the usage of averaged measures of resources and institutional quality does not alter the results.

Although the abundance of resources might not guarantee prosperity, a country with rich resources has had more opportunities to become prosperous. This study confirms such common sense. Natural resources may or may not worsen the quality of institutions, but there is little evidence that large endowments of oil or natural gas harm the economic growth of a country. Rather, countries rich in resources are confirmed to be actually richer than countries without such resources. 


\section{[References]}

1. Alexeev, Michael, and Robert Conrad, "The Elusive Curse of Oil," Review of Economics and Statistics, Vol. 91, No. 3, 2009, pp. 586 598.

2. Aslaksen, Silje, "Oil and Democracy: More than a Cross-country Correlation?," Journal of Peace Research, Vol. 47, No. 4, 2010, pp. 421 431.

3. BP, BP Statistical Review of World Energy 2005. 2005.

4. BP, BP Statistical Review of World Energy 2008. 2008.

5. Carneiro, Francisco G., "Development Challenges of Resource-rich Countries: The Case of Oil Exporters," Proceedings of the VI International Colloquium, 2007, pp. $115 \sim 140$.

6. CIA, CIA World Factbook 2008. 2008.

7. Collier, Paul and Benedikt Goderis, "Commodity Prices, Growth, and the Natural Resource Curse: Reconciling a Conundrum," MPRA Working Paper, No. 17315, June 2008.

8. Easterly, W., and R. Levine, "Tropics, Germs, and Crops: How Endowments Influence Economic Development," Journal of Monetary Economics, Vol. 50, 2003, pp. 3 39.

9. Gylfason, Thorvaldur, "Natural Resources, Education, and Economic Development," European Economic Review, Vol. 45, No. 4 6, 2001, pp. 847 859.

10. Hall, Robert E. and Charles I. Jones, "Why Do Some Countries Produce so Much More Output per Worker than Others?," Quarterly Journal of Economics, Vol. 114, 1999, pp. 83 116.

11. Heston, Alan, Robert Summers, and Bettina Aten, Penn World Table Version 6.2, Center for International Comparisons of Production, Income and Prices at the University of Pennsylvania, September 2006.

12. Hodler, Roland, "The Curse of Natural Resources in Fractionalized Countries," European Economic Review, Vol. 50, No. 6, August 2006, pp. 1367 86.

13. Kim, Dong Koo, "The Perplexing Curse of Natural Resources," Master's Thesis, Seoul National University, 2009.

14. Maddison, A., Statistics on World Population, GDP and Per Capita GDP, 1-2006 $A D, 2008$. 
15. Matsen, Egil and Ragnar Torvik, "Optimal Dutch Disease," Journal of Development Economics, Vol. 78, No. 2, December 2005, pp. 494 515.

16. Mehlum, H., K. Moene, and R. Torvik, "Institutions and the Resource Curse," Economic Journal, Vol. 116, 2006, pp. 1 20.

17. Parker, Philip M., National Cultures of the World: A Statistical Reference, Cross-Cultural Statistical Encyclopedia of the World, Vol. 4, Greenwood Press, Westport, CT, 1997.

18. Rodrik, Dani, Arvind Subramanian, and Francesco Trebbi, "Institutions Rule: The Primacy of Institutions Over Geography and Integration in Economic Development," Journal of Economic Growth, Vol. 9, 2004, pp. 131 165.

19. Philip G. Roeder, Ethnolinguistic Fractionalization (ELF) Indices, 1961 and 1985, online database: http//:weber.ucsd.edul proederlelf.htm, 2001.

20. Polterovich, Victor, Bladimir Popov, and Alexander Tonis, "Resource Abundance: A Curse or Blessing?," DESA Working Paper, No. 93, June 2010.

21. Sachs, Jeffrey D. and Andrew M. Warner, "Natural Resource Abundance and Economic Growth," NBER Working Papers, No. 5398, 1995.

22. Sachs, Jeffrey D. and Andrew M. Warner, "The Curse of Natural Resources," European Economic Review, Vol. 45, 2001, pp. 827 838.

23. Sala-i-Martin, X., G. Doppelhofer, and R. Miller, "Determinants of Long-Term Growth: A Bayesian Averaging of Classical Estimates (BACE) Approach," American Economic Review, Vol. 94(4), 2004, pp. 813 835.

24. Torvik, Ragnar, "Learning by Doing and the Dutch Disease," European Economic Review, Vol. 45, No. 2, 2001, pp. 285 306.

25. Torvik, Ragnar, "Natural Resources, Rent Seeking and Welfare," Journal of Development Economics, Vol. 67, No. 2, 2002, pp. 455 470.

26. Torvik, Ragnar, "Why Do Some Resource-abundant Countries Succeed While Others Do Not?," Oxford Review of Economic Policy, Vol. 25, No. 2, 2009, pp. 241 256.

27. Treisman, Daniel, "Is Russia Cursed by Oil?," Journal of International Affairs, Vol. 63, No. 2, 2010, pp. 85 102.

28. World Bank, Aggregate Governance Indicators 1996-2007. World Bank website. http://www.worldbank.org/wbi/governance, 2008. 


\section{Appendix}

〈Table A1〉 Data Description and Sources

\begin{tabular}{|c|c|c|}
\hline Variable & Description & Source \\
\hline Absolute latitude & Absolute value of the latitude of the country. & CIA (2008) \\
\hline Africa & Dummy variable for Sub-Sahara African countries. & \\
\hline Capital-Labor ratio & Capital Stock per Worker in year 2000 & PWT6.2 \\
\hline Communist, former & $\begin{array}{c}\text { Dummy variable equal to } 1 \text { if country has been a } \\
\text { communist economy. }\end{array}$ & Parker (1997) \\
\hline East Asia & Dummy variable for East Asian countries. & \\
\hline English speakers & $\begin{array}{l}\text { Fraction of population whose mother tongue is } \\
\text { English. }\end{array}$ & Parker (1997) \\
\hline $\begin{array}{l}\text { Ethniclinguistic } \\
\text { fractionalization } \\
\text { (ELF) }\end{array}$ & An index of ethnolinguistic fractionalization. & Roeder (2001) \\
\hline European language & $\begin{array}{c}\text { Fraction of population whose mother tongue is one } \\
\text { of four primary Western European languages - } \\
\text { English, French, German, and Spanish. }\end{array}$ & Parker (1997) \\
\hline European population & Dummy variable for a European population. & \\
\hline $\begin{array}{l}\text { GDP } 1973, \text { per } \\
\text { capita (actual) }\end{array}$ & $\begin{array}{l}\text { Logarithm of per capita PPP GDP in year 1973, } \\
\text { Calculated from per capita GDP in year } 1973 .\end{array}$ & $\begin{array}{l}\text { Maddison }(2008) \\
\text { or PWT6.2 } \\
\end{array}$ \\
\hline $\begin{array}{l}\text { GDP } 1973 \text {, per } \\
\text { capita (predicted 1) }\end{array}$ & $\begin{array}{l}\text { Predicted values of logarithm of per capita PPP } \\
\text { GDP in year } 1973 \text { from equations (5) and (7) }\end{array}$ & \\
\hline $\begin{array}{l}\text { GDP } 1973 \text {, per } \\
\text { capita (predicted 2) }\end{array}$ & $\begin{array}{l}\text { Predicted values of logarithm of per capita PPP } \\
\text { GDP in year } 1973 \text { from equations (6) and (8) }\end{array}$ & \\
\hline $\begin{array}{l}\text { GDP } 2000, \text { per } \\
\text { capita }\end{array}$ & $\begin{array}{l}\text { Logarithm of per capita PPP GDP in year } 2000 \text {, } \\
\text { Calculated from per capita GDP in year } 2000 .\end{array}$ & PWT6.2 \\
\hline $\begin{array}{l}\text { GDP } 2006 \text {, per } \\
\text { capita }\end{array}$ & $\begin{array}{l}\text { Logarithm of per capita PPP GDP in year } 2006 \text {, } \\
\text { Calculated from per capita GDP in year } 2006 .\end{array}$ & Maddison (2008) \\
\hline $\begin{array}{c}\text { Hydrocarbon } \\
\text { deposits, per capita }\end{array}$ & Logarithm of hydrocarbon deposits in year 1993 . & $\begin{array}{l}\text { Sala-i-Martin et } \\
\text { al. (2004) }\end{array}$ \\
\hline Landlocked & $\begin{array}{l}\text { Dummy variable equal to } 1 \text { if country does not } \\
\text { adjoin the sea. }\end{array}$ & Parker (1997) \\
\hline Latin America & Dummy variable for Latin American countries. & \\
\hline $\begin{array}{c}\text { Natural gas reserve, } \\
\text { per capita }\end{array}$ & $\begin{array}{l}\text { Logarithm of one plus natural gas reserve per } \\
\text { capita in year } 2007 .\end{array}$ & CIA (2008) \\
\hline $\begin{array}{l}\text { Oil reserve, per } \\
\text { capita }\end{array}$ & $\begin{array}{c}\text { Logarithm of one plus oil reserve per capita in } \\
\text { year } 2007 .\end{array}$ & CIA (2008) \\
\hline
\end{tabular}


〈Table A1〉 Data Description and Sources (continued)

\begin{tabular}{c|c|c}
\hline Variable & Description & Source \\
\hline Oil/GDP ratio & $\begin{array}{c}\text { Logarithm of one plus the value of oil output in } \\
2000 \text { divided by PPP GDP from Maddison (2008) }\end{array}$ & $\begin{array}{c}\text { Maddison (2008), } \\
\text { Oil ouput is from } \\
\text { BP (2008) }\end{array}$ \\
\hline $\begin{array}{c}\text { Protestant population } \\
\text { share }\end{array}$ & Share of Protestant population in the country. & Parker (1997) \\
\hline Rule of law & Rule of law index for 2006. & $\begin{array}{c}\text { World Bank } \\
\text { (2008) }\end{array}$ \\
\hline $\begin{array}{c}\text { Value of natural gas } \\
\text { output, per capita }\end{array}$ & $\begin{array}{c}\text { Logarithm of one plus the value (at world market } \\
\text { price in 2007 US\$) of country's per capita natural } \\
\text { gas output in year 2007. }\end{array}$ & $\begin{array}{c}\text { CIA (2008). Price } \\
\text { is from BP (2008) }\end{array}$ \\
\hline $\begin{array}{c}\text { Value of oil output, } \\
\text { per capita }\end{array}$ & $\begin{array}{c}\text { Logarithm of one plus the value (at world market } \\
\text { price in 2007 US\$) of country's per capita oil } \\
\text { output in year 2007. }\end{array}$ & $\begin{array}{c}\text { CIA (2008). Price } \\
\text { is from BP (2008) }\end{array}$ \\
\hline $\begin{array}{c}\text { Value of oil output } \\
\text { in 2000, per capita }\end{array}$ & $\begin{array}{c}\text { Logarithm of one plus the value (at world market } \\
\text { price in 2000 US\$) of country's per capita oil } \\
\text { output in year 2000. }\end{array}$ & $\begin{array}{c}\text { Oil output and } \\
\text { price are from BP } \\
\text { (2008) }\end{array}$ \\
\hline
\end{tabular}

